Prepared for the U.S. Department of Energy

under Contract DE-AC05-76RL01830

\title{
Further Studies on Uncertainty,
}

Confounding, And Validation of the Doses in the Techa River Dosimetry System: Concluding Progress Report on the Second Phase of Project 1.1
OM Degteva
BA Napier
LR Anspaugh

October 2009

Pacific Northwest

NATIONAL LABORATORY

Proudly Operated by Battelle Since 1965 


\title{
DISCLAIMER
}

This report was prepared as an account of work sponsored by an agency of the United States Government. Neither the United States Government nor any agency thereof, nor Battelle Memorial Institute, nor any of their employees, makes any warranty, express or implied, or assumes any legal liability or responsibility for the accuracy, completeness, or usefulness of any information, apparatus, product, or process disclosed, or represents that its use would not infringe privately owned rights. Reference herein to any specific commercial product, process, or service by trade name, trademark, manufacturer, or otherwise does not necessarily constitute or imply its endorsement, recommendation, or favoring by the United States Government or any agency thereof, or Battelle Memorial Institute. The views and opinions of authors expressed herein do not necessarily state or reflect those of the United States Government or any agency thereof.

\author{
PACIFIC NORTHWEST NATIONAL LABORATORY \\ operated by \\ BATTELLE \\ for the \\ UNITED STATES DEPARTMENT OF ENERGY \\ under Contract DE-AC05-76RL01830
}

Printed in the United States of America
Available to DOE and DOE contractors from the Office of Scientific and Technical Information,
P.O. Box 62, Oak Ridge, TN 37831-0062;
ph: (865) 576-8401
fax: $(865)$ 576-5728
email: reports@adonis.osti.gov

\begin{abstract}
Available to the public from the National Technical Information Service, U.S. Department of Commerce, 5285 Port Royal Rd., Springfield, VA 22161 ph: (800) 553-6847 fax: $(703) 605-6900$ email: orders@ntis.fedworld.gov online ordering: http://www.ntis.gov/ordering.htm
\end{abstract}

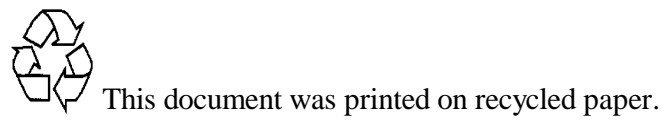




\title{
FURTHER STUDIES ON UNCERTAINTY, CONFOUNDING, AND VALIDATION OF THE DOSES IN THE TECHA RIVER DOSIMETRY SYSTEM
}

\author{
Submitted to the Office of International Health Studies, U.S. Department of Energy \\ for the \\ U.S.-Russia Joint Coordinating Committee on Radiation Effects Research \\ Concluding Progress Report on the Second Phase of Project 1.1
}

\section{Principal Investigators:}

For Russia:

Marina Degteva

For the United States:

Lynn Anspaugh and Bruce Napier

\section{Participating Institutions:}

For Russia:

Urals Research Center for Radiation Medicine, Chelyabinsk

For the United States:

University of Utah, Salt Lake City, UT

Pacific Northwest National Laboratory, Richland, WA

October 2009 


\section{TABLE OF CONTENTS}

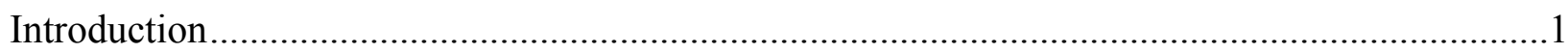

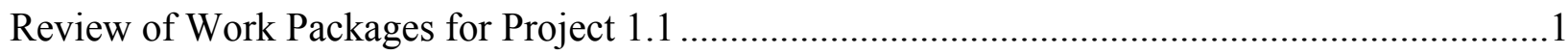

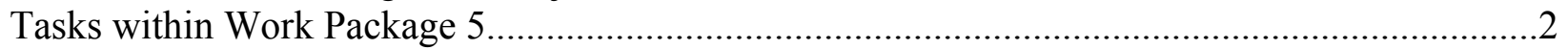

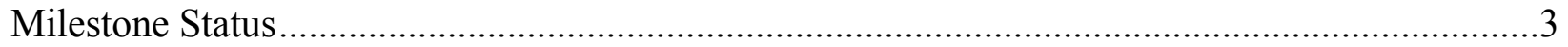

Proposed New Work Packages and Tasks for FY2010 through FY2012 _..............................7

Proposed New Deliverables and Milestone for FY2010 through FY2012 ............................... 9

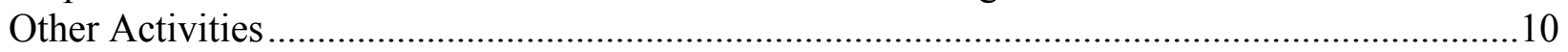

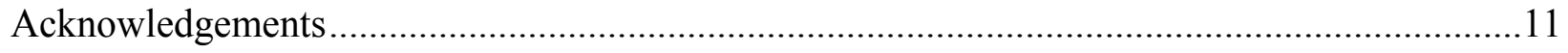

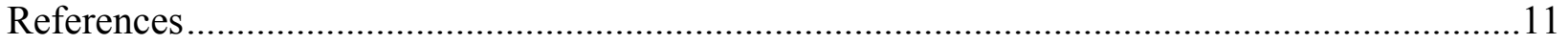

Appendix 1. Updated List of Publications for Project 1.1 ...................................................16

Note-We have stopped our usual practice of including copies of recent publications as appendices to this report. Publications are available upon request.

International Copyright (C) 2009 by the Urals Research Center for Radiation Medicine. All rights reserved. 


\section{INTRODUCTION}

This is the concluding Progress Report for Project 1.1 of the U.S.-Russia Joint Coordinating Committee on Radiation Effects Research (JCCRER). In keeping with the request of November 2008 of the members of the American Scientific Review Group (AmSRG), this report continues in the abbreviated format of providing details only on the work accomplished during this six-month reporting period.

An overwhelming majority of our work this period has been to complete our primary obligation of providing a new version of the Techa River Dosimetry System (TRDS), which we call TRDS-2009D; the D denotes deterministic. This system provides estimates of individual doses to members of the Extended Techa River Cohort (ETRC) and post-natal doses to members of the Techa River Offspring Cohort (TROC). The latter doses were calculated with use of the TRDS-2009D. The doses for the members of the ETRC have been made available to the American and Russian epidemiologists in September for their studies in deriving radiogenic risk factors. Doses for members of the TROC are being provided to European and Russian epidemiologists, as partial input for studies of risk in this population. Project 1.1 was not charged with providing in utero doses, and that is the responsibility of European and Russian investigators.

Two of our original goals for the completion of this nine-year phase of Project 1.1 were not completed. These are completion of TRDS-2009MC, which was to be a Monte Carlo version of TRDS-2009 that could be used for more explicit analysis of the impact of uncertainty in doses on uncertainty in radiogenic risk factors. The second incomplete goal was to be the provision of household specific external doses (rather than village average). This task was far along, but had to be delayed due to the lead investigator's work on consideration of a revised source term.

\section{REVIEW OF WORK PACKAGES FOR PROJECT 1.1}

The work for Project 1.1 had been divided into five Work Packages (WP), and these are listed below.

WP-1. Improvements in basic models and further evaluation of uncertainty.

WP-2. Reduction in uncertainty: reassessment of internal doses on the basis of individual measurements and household analogies.

WP-3. Validation of TRDS external doses by combining EPR results with modeling.

WP-4. Evaluation of other sources of exposure that confound the analysis of data for members of the ETRC and the TROC.

WP-5. Development of a new version of the Techa River Dosimetry System (TRDS) code for individual-dose calculations. This revised code will include all sources of exposure, including updates for the calculation of dose from consumption of contaminated water and foods associated with releases to the Techa River. 
All tasks within WP-1, WP-2, WP-3 and WP-4 were completed before October 2006. Efforts on these tasks supported twenty milestone or unscheduled reports; the current accomplishments have been described in numerous publications (Appendix 1) and have been summarized in Degteva et al. (2006). Because of changes in the source-term and because additional data on external exposure rates were successfully renormalized, three additional unscheduled reports were prepared and distributed with the April 2009 Progress Report.

\section{TASKS WITHIN WORK PACKAGE 5}

Task 5.1. Comparative analysis of potential contributions from different sources of confounding exposure for the members of the ETRC (M. Degteva).

Task 5.2. Development of an algorithm for selection of the best individual estimate of internal dose on the basis of the results of calculations performed using three different protocols (N. Shagina).

Task 5.3. Development of the special code and calculation of individual medical doses for members of the ETRC. (M. Degteva and V. Golikov).

Task 5.4. Creation of the TRDS modules for the calculation of short-lived radionuclides intake on the basis of verified source-term data (M. Vorobiova and E. Tolstykh).

Task 5.5. Creation of the TRDS modules for the calculation of external doses on the basis of verified source-term data (M. Vorobiova).

Task 5.6. (former Task 5.3). Preparation of a protocol for individual-dose reconstruction (M. Degteva and A. Kozyrev).

Task 5.7. Development of the TRDS code and calculation of individual doses for members of the ETRC. (M. Degteva and A. Kozyrev).

Task 5.8. Development of the stochastic TRDS code to be used to evaluate the impact of uncertainty in individual dose upon derived risk coefficients (N. Shagina and M. Degteva).

Tasks 5.1, 5.2, 5.3, 5.4, 5.5, and 5.6 had been completed before this reporting period; eight Milestone or Unscheduled Reports were previously distributed that describe the work on these Tasks. Tasks 5.6 and 5.7 were completed during this six-month period. The results of the two tasks resulted in the creation of TRDS-2009D. Our Final Report for Milestone 22 (Degteva et al. 2009b) describes the results of these four tasks and the results calculations of individual dose for the members of the ETRC and of post-natal doses for members of the TROC.

As noted before and as stated in our previous Progress Report, it was not possible to complete Task 5.8. We have prepared a Status Report (Napier et al. 2009) on Task 5.8, which is 
being distributed with this Progress Report. As planned and indicated in our recent proposal (Degteva et al. 2009a) for continuation of Project 1.1, this task will be completed at a later date.

\section{MILESTONE STATUS}

As this is the Concluding Progress Report for this phase of Project 1.1, the status of all Milestones for the phase is reviewed. This is the last time that these milestones will be listed in our Progress Reports.

1. Statistical analysis of individual dosimetric data and the evaluation of uncertainties in instrumental techniques used for ${ }^{90} \mathrm{Sr}$-body-burden evaluation (whole-body count and toothbeta count).

Completed in October 2000 with the delivery of the Milestone 1 Report (Kozheurov et al. 2000).

2. Description of the computer database "TOOTH" containing available EPR measurements on tooth samples and exposure histories of tooth donors for the ETRC members and the residents of background areas.

Completed in April 2001 with the delivery of the Milestone 2 Report (Shishkina et al. 2001).

3. Report on basic models for ${ }^{90} \mathrm{Sr}$-dose assessments: improved strontium biokinetic model and verified ${ }^{90} \mathrm{Sr}$-intake model.

Part 1 was completed in September 2001 with the delivery of the Milestone 3, Part 1, Report (Tolstykh et al. 2001).

Part 2 was completed in April 2002 with the delivery of the Milestone 3, Part 2, Report (Shagina et al. 2002b).

An Unscheduled Report Dosimetric models for strontium in the human bone: A review of available data and researches needed (Shagina et al. 2005) was prepared in 2005.

Another Unscheduled Report Improvement in Strontium-90 reference intake function for residents of the Techa Riverside settlements (Tolstykh et al. 2008a) was prepared in October 2008 and distributed with our previous Progress Report.

4. Description of the Individual-to-Model Ratio (IMR) Registry (or Subcohort 1), which includes the list of measured ETRC members with IMR values and their uncertainties.

A Progress Report for Milestone 4 (Shagina et al. 2002a) was distributed in February 2002. 
The Final Report for Milestone 4 (Tolstykh et al. 2002) was completed and distributed in October 2002.

5. Report on an improved Techa River Model and evaluation of uncertainties in radionuclide composition of river water. Verification of intake levels and their uncertainties for non- ${ }^{90} \mathrm{Sr}$ radionuclides.

The Final Report for Milestone 5 (Vorobiova et al. 2003a) was completed and distributed in April 2003.

An Unscheduled Report, Improvement in cesium-137 intake with milk contaminated as a result of soil $\rightarrow$ grass $\rightarrow$ milk transfer (Tolstykh et al. 2008b) was prepared and distributed with our previous progress report.

6. Description of the Household Registry for the Techa River settlements that includes a list of ETRC members with household codes, settlement codes and the dates of cohabitation.

The Final Report for Milestone 6 (Tokareva et al. 2003) was completed and distributed in April 2003.

7. Report on the validation of TRDS external dose assessments by EPR measurements supported by the assessments of ${ }^{90} \mathrm{Sr}$ concentration in tooth tissues and Monte Carlo simulations of dose distribution through human tissues.

An Unscheduled Report Commentary on the number of teeth required for analysis by EPR in order to validate estimates of external dose for members of the extended Techa River Cohort (Anspaugh et al. 2001) was prepared in 2001.

Another Unscheduled Report Investigation of the tooth as a complex dosimeter: Formation of dose in tooth enamel was distributed in June 2002 (Shishkina et al. 2002).

Part 1 was completed in September 2003 with the delivery of the Milestone 7, Part 1, Report (Shishkina et al. 2003).

Part 2 was completed in September 2004 with the delivery of the Milestone 7, Part 2, Report (Degteva et al. 2004).

8. Description of the algorithm for the evaluation of uncertainty in Household-Specific-Ratios (HSR) and Subcohort 2 that includes the list of unmeasured ETRC members with HSR values and their uncertainties.

The Final Report for Milestone 8 (Tolstykh et al. 2003) was completed and distributed in October 2003.

9. Report on the uncertainties in TRDS external dose estimates evaluated on the basis of modeling data and the distributions of external exposure components of EPR measurements. 
The Final Report for Milestone 9 (Degteva et al. 2005a) was completed and distributed in April 2005.

An Unscheduled Report Methodological approaches to evaluation of parameters for external exposure of the Techa River residents (Vorobiova et al. 2008) was prepared and distributed with our previous progress report.

10. Analytical review of data and models available for the reconstruction of individual doses due to residence on the EURT area and the territory of windblown contamination from Lake Karachay.

The Final Report for Milestone 10 (Peremyslova et al. 2004) was completed and distributed in May 2004.

11. Analysis of the territorial distribution of residence locations for members of the ETRC within the EURT and Karachay Trace areas with different levels of soil contamination.

The combined Report for Milestones 11 and 12 (Tolstykh et al 2006) was completed and distributed in April 2006.

12. Description of available databases and the methodological approaches to the reconstruction of radionuclide intake for the EURT and 'Karachay Trace' areas.

The combined Report for Milestones 11 and 12 (Tolstykh et al 2006) was completed and distributed in April 2006.

13. Report on methodological approaches to external dose reconstruction and validation for the EURT and Karachay Trace areas.

The Final Report for Milestone 13 (Vorobiova et al. 2006) was completed and distributed in September 2006.

14. Comparative analysis of the possible impact of different sources of environmental and medical exposure for referent persons.

The Final Report for Milestone 14 (Degteva et al. 2007a) has been completed and was distributed in April 2007.

15. Final Report for Project 1.1 including a Protocol (algorithm) for individual-dose reconstruction due to different sources of confounding exposure for the members of the ETRC. Description will also be given for the structure of a revised Dosimetric System.

This effort has been completed. The results are included in the Milestone 22 Report (Degteva et al. 2009b), which is being distributed with this Progress Report.

16. (Milestone 1 of the Addendum) Description of the "Registry of X-Ray Procedures" that will include a list of members of the ETRC with the dates and types of radiological examinations that were experienced since 1956. 
The Final Report for Milestone 16 (Vorobiova et al 2003b) was completed and distributed in November 2003.

17. (Milestone 2 of the Addendum) Protocol for the reconstruction of individual medical doses for members of the ETRC.

The Final Report for Milestone 17 (Degteva et al. 2005b) was completed and distributed in September 2005.

18. Algorithm for selection of the best individual estimate of internal dose on the basis of the results of calculations performed using three different protocols.

The Final Report for Milestone 18 (Shagina et al. 2007) has been completed and distributed in April 2007.

19. Milestone 19. Report describing the results of calculations of individual medical doses for members of the ETRC.

The Final Report for Milestone 19 (Degteva et al. 2007b) was completed in October 2007 and distributed in April 2008.

20. Milestone 20. Description of the TRDS modules for the calculation of short-lived radionuclides intake and external doses on the basis of verified source-term data using the two-compartment river model.

Part 1 of the combined Report for Milestones 20 and 21 (Degteva et al 2008) was completed and was distributed with the April 2009 Progress Report.

Part 2 (Degteva et al. 2009c) was also distributed with the April 2009 Progress Report.

21. Milestone 21. Description of a protocol (algorithm) for individual-dose reconstruction due to different sources of confounding exposure for the members of the ETRC. Description will also be given for the structure of a revised Dosimetric System.

Part 1 of the combined Report for Milestones 20 and 21 (Degteva et al 2008) was completed and was distributed with the April 2009 Progress Report.

Part 2 (Degteva et al. 2009c) was also distributed with the April 2009 Progress Report.

22. Milestone 22. Report describing the results of calculations of individual doses for members of the ETRC using the improved TRDS code including different sources of confounding exposure.

Delayed due to funding cuts. The Milestone 22 Report (Degteva et al. 2009b) is being distributed with this Progress Report. 
23. Report describing the development of the stochastic version of the TRDS code and the results of several iterations of individual doses for the approximately 30,000 members of the ETRC.

Due to budget cuts, it was not possible to complete this Milestone Report. A status report (Napier et al. 2009) is being distributed with this Progress Report.

\section{PROPOSED NEW WORK PACKAGES AND TASKS FOR FY2010 THROUGH FY2012}

These tasks are taken from our proposal (Degteva et al. 2009a) for an extension to this project.

The proposed efforts include specific tasks linked to improvements in the basic models used for dose reconstruction, validation of the improved models, extensions to the current version of the TRDS-2009 code and completion of the stochastic version.

\section{WP-1. River modeling and data harmonization}

Task 1.1. Evaluation of historical methods for measurements of gamma- and beta-radiation with the use of Monte Carlo modeling of radiation transport.

This task will allow evaluation of possible systematic errors in historical measurements (dated 1950-1956) for some source-term radionuclides in dependence of the energy of beta-particles or photons.

Task 1.2. Development of a dynamic model for radionuclide transport in the Techa River.

Work on this task will develop the model for radionuclide transport through the Koksharov and Metlinsky ponds, potential deposition and resuspension from the Metlino and Asanov Marshes, and transport along the river. The model will provide concentrations of all source term radionuclides at all village locations, with due account take of radioactive decay. The model will include sediment concentrations, which will be used to estimate external dose rates at locations downstream.

Task 1.3. Harmonization of historical data and river model output.

This task will examine the results of the output of the dynamic Techa River model of Task 1.2 in comparison to historical measurements of the river water and sediments, as

well as the ${ }^{90} \mathrm{Sr}$ intake function developed in retrospective fashion from the tooth-beta and whole-body measurements. This could lead to refinement of the Techa River source term, particularly the relative ratios of short-lived nuclides to strontium and cesium. Depending upon the outcome of the comparisons, this could result in an iterative approach to determining the source term. 


\section{WP-2. Reduction in uncertainty and validation of TRDS external doses}

Task 2.1. Completion of work on associating individuals with a geographic location of their homes for the upper Techa region.

The result of this task will the location of individual households in the villages between Metlino and Muslyumovo. Distances between the river shore and the households will be associated with the individuals within the database.

Task 2.2. Evaluation of household-based deterministic estimates of individual external doses for all individuals associated with the geographic locations of their homes.

Registry of household-based deterministic estimates of individual external doses will be created, a computer program will be written to automate this currently-manual operation.

Task 2.3. Verification and validation of external doses.

Continued evaluation will be made of available and new luminescence measurements (TLD), electron paramagnetic resonance measurements (EPR), and fluorescent in situ hybridization (FISH) measurements with human lymphocytes obtained under the SOUL project, to confirm that the changes made in Tasks 1.3 and 2.2 are compatible with the available monitoring data.

\section{WP-3. Further reduction in uncertainty of TRDS internal doses}

Task 3.1. Examination of the results of measurements of ${ }^{90} \mathrm{Sr}$-body burdens with use of the upgraded WBC system.

It is planned to increase the number of newly measured individuals up to 3,500. Evaluation of these results will provide an important addition to our data base.

Task 3.2. Comparison of data obtained with the old and new WBC systems for persons with high concentrations of ${ }^{90} \mathrm{Sr}$.

This task will allow pooled analysis of ${ }^{90}$ Sr-body burdens measured in 1974-1997 and after 2006.

Task 3.3. Updating of the IMR and HSR registries with use of data derived from newlymeasured persons.

This task will allow an increase in the number of cohort members with refined estimates of internal dose.

WP-4. Enhancements in the TRDS

Task 4.1. Incorporation of EURT evacuated villages. 
This task will result in the collection of data necessary to estimate doses with existing algorithms for residents in those villages that were evacuated following the 1957 creation of the EURT.

Task 4.2. Consideration of the release from the MPA stack as confounding source of exposure.

This task will allow making a decision on whether to incorporate doses from airborne releases from the Mayak reactor and fuel processing stacks.

Task 4.3. Re-calculation of TRDS-2009D modules supporting computations of external doses and intakes of non- ${ }^{90} \mathrm{Sr}$ radionuclides.

This task will incorporate the results of Tasks 1.3 and 2.3 into the TRDS-2009D databases.

Task 4.4. Completion of the stochastic TRDS-2009MC computer code.

The stochastic version of the TRDS code will include all sources of exposure as within the deterministic version. However, parameters within the code will be assigned distributions. These parameters will be allowed to vary during each iteration of the process with due consideration of which parameters are shared versus those that may vary on an individual basis. Distinction will be made between Classical and Berksontype error structures. The recent improvement of knowledge about the Techa River source term (e.g., Degteva et al. 2008a; b) adds computational complexity, but does not alter the basic structure proposed.

\section{PROPOSED NEW DELIVERABLES AND MILESTONES FOR FY2010 THROUGH FY2012}

The dates given below are given with the assumption that funding would have been received on October 1, 2009.

1. Evaluation of historical methods for measurements of gamma- and beta-radiation with the use of Monte Carlo modeling of radiation transport. (E. Shishkina).

Task 1.1 - March 2010

2. Description of a dynamic model for the transport of radionuclides within the Techa River and comparison of model results with historical measurements (M. Vorobiova and M. Degteva).

Tasks 1.2 and 1.3 - September 2010

3. Individualization and validation of external doses for the upper Techa River villages (E. Tokareva and E. Shishkina) 
Tasks 2.1, 2.2 and 2.3 - March 2011

4. Comparison of data obtained with the old and new WBC systems for persons with high contents of ${ }^{90} \mathrm{Sr}(\mathrm{N}$. Bougrov and E. Tolstykh)

Tasks 3.1 and $3.2-$ September 2011

5. Description of the revisions to TRDS-2009D code and databases (M. Vorobiova, E. Tolstykh and A. Kozyrev)

Tasks 3.3, 4.1, 4.2 and 4.3 - March 2012

6. Description of the TRDS-2009MC computer code and stochastic dose estimates (M. Degteva and N. Shagina)

Task 4.4 - September 2012

\section{OTHER ACTIVITIES}

We continue to be in close contact with the investigators of our companion US epidemiologic studies. We also are part of and maintain close contact with all investigators of the related studies being conducted by the European Union in the framework of their SOUL project.

We continue to publish papers and to participate in scientific meetings, although this activity has slowed due to the pressure to complete TRDS-2009D. We did participate in the NCI-sponsored conference, "Late Health Effects of Ionizing Radiation: Bridging the Experimental and Epidemiologic Divide Conference," Washington DC, USA, May 4-6, 2009, (Degteva et al. 2009d; Krivoshchapov and Shishkina 2009a; Shagina et al. 2009) and we provided an abstract and a summary for the Annual Meeting of the JCCRER, September 16-17, 2009. One of our young investigators participated in the 2009 annual meeting of the Health Physics Society (Krivoshchapov and Shishkina 2009b).

A paper, "Bone Tissue Reactions to ${ }^{90} \mathrm{Sr}$ radiation exposure: Analyses of data from Techa Riverside residents," has been prepared and will be submitted to a journal in the near future. This activity was also funded by the Russian Foundation for Basic Research Grant 07-04-96084.

A complete list of project publications is given in Appendix 1. Additions since the last Progress Report are shaded. 


\section{ACKNOWLEDGEMENTS}

This work has been funded by the US Department of Energy's Office of International Health Studies, the US Environmental Protection Agency's Office of Radiation and Indoor Air, and the Federal Medical-Biological Agency of the Russian Federation.

\section{REFERENCES}

Anspaugh LR, Degteva MO, Shishkina EA, Tolstykh EI, Napier BA. Commentary on the number of teeth required for analysis by EPR in order to validate estimates of external dose for members of the extended Techa River Cohort. Chelyabinsk and Salt Lake City: Urals Research Center for Radiation Medicine and University of Utah; Unscheduled Report on Project 1.1; September 2001.

Degteva MO, Vorobiova MI, Shved VA, Shishkina EA, Ivanov DV, Bayankin SN, Tolstykh EI, Zalyapin VI, Wieser A, Jacob P, Anspaugh LR, Napier BA. Validation of TRDS external dose estimates by EPR measurements supported by assessments of strontium-90 concentration and Monte Carlo simulations of electron transport in dental tissues. Chelyabinsk and Salt Lake City: Urals Research Center for Radiation Medicine and University of Utah; Final report for Milestone 7, Part 2; September 2004 (in Russian and English).

Degteva MO, Vorobiova MI, Akhramenko BN, Shagina NB, Safronova NG, Anspaugh LR, Napier BA. Report on the uncertainties in TRDS external dose estimates evaluated on the basis of modeling data and the distributions of external exposure components of EPR measurements. Chelyabinsk and Salt Lake City: Urals Research Center for Radiation Medicine and University of Utah; Final report for Milestone 9; April 2005a.

Degteva MO, Golikov VYu, Vorobiova MI, Barkovsky AN, Zubkova TI, Kozyreva OV, Anspaugh LR, Napier BA. Development of the protocol for the reconstruction of individual medical doses for members of the ETRC. Chelyabinsk and Salt Lake City: Urals Research Center for Radiation Medicine and University of Utah; Final report for Milestone 17; September 2005b (in Russian and English).

Degteva MO, Tolstykh EI, Vorobiova MI, Shagina NB, Shishkina EA, Bougrov NG, Anspaugh LR, Napier BA. Techa River Dosimetry System: Current status and future. Radiat Safety Problems (Mayak Production Association Scientific Journal) № 1:66-80; 2006 (in Russian). English translation is available at http://biophys.urcrm.chel.su.

Degteva MO, Tolstykh EI, Vorobiova MI, Shagina NB, Anspaugh LR, Napier BA. Comparative analysis of the possible impact of different sources of environmental and medical exposure for members of the Techa River cohorts. Chelyabinsk and Salt Lake City: Urals Research Center for Radiation Medicine and University of Utah; Final report for Milestone 14; April 2007a.

Degteva MO, Shagina NB, Vorobiova MI, Golikov Vyu, Barkovsky AN, Kozyrev AV, Anspaugh LR, Napier BA. Reconstruction of individual medical doses for members of the Extended Techa River Cohort. Chelyabinsk and Salt Lake City: Urals Research Center for 
Radiation Medicine and University of Utah; Final report for Milestone 19; October 2007b (in Russian and English).

Degteva MO, Tolstykh EI, Vorobiova MI, Shagina NB, Anspaugh LR, Napier BA. Structure of the revised Techa River Dosimetry System: General approach and evaluation of sourceterm parameters. Chelyabinsk and Salt Lake City: Urals Research Center for Radiation Medicine and University of Utah; Combined Report for Milestones 20 and 21, Part 1. October 2008.

Degteva MO, Anspaugh L, Napier B. Enhancements in the Techa River Dosimetry System. Proposal for the continuation of Project 1.1. Chelyabinsk and Salt Lake City: Urals Research Center for Radiation Medicine and University of Utah; April 2009a.

Degteva MO, Shagina NB, Tolstykh EI, Vorobiova MI, Anspaugh LR, Napier BA. Individual dose calculations with use of the revised Techa River Dosimetry System TRDS-2009D. Chelyabinsk and Salt Lake City: Urals Research Center for Radiation and Medicine and University of Utah; Final report for Milestone 22; 2009b.

Degteva MO, Tolstykh EI, Vorobiova MI, Shagina NB, Kozyrev AV, Anspaugh LR, Napier BA. Structure of the revised Techa River Dosimetry System: Exposure pathways and system databases. Chelyabinsk and Salt Lake City: Urals Research Center for Radiation Medicine and University of Utah; Combined report for Milestones 20 and 21, Part 2. April 2009c.

Degteva MO, Tolstykh EI, Vorobiova MI, Shagina NB, Anspaugh LR, Napier BA. Structure of a new Techa River Dosimetry System: General approach and evaluation of parameters. In: Late health effects of ionizing radiation: Bridging the experimental and epidemiologic divide conference, Washington DC, USA, May 4-6, 2009. Scientific programme and book of abstracts. Bethesda: National Cancer Institute; 2009d:20.

Kozheurov VP, Zalyapin VI, Shagina NB, Tokareva EE, Degteva MO, Tolstykh EI, Anspaugh LR, Napier BA. Statistical analysis of individual dosimetric data and the evaluation of uncertainties in instrumental techniques used for 90Sr-body burden evaluation (whole body count and tooth-beta count). Chelyabinsk and Salt Lake City: Urals Research Center for Radiation Medicine and University of Utah; Final report for Milestone 1; September 2000.

Krivoshchapov VA, Shishkina EA. PSL method for evaluation of spatial distribution of 90Sr in biological samples. In: Late health effects of ionizing radiation: Bridging the experimental and epidemiologic divide conference, Washington DC, USA, May 4-6, 2009. Scientific programme and book of abstracts. Bethesda: National Cancer Institute; 2009a: 67.

Krivoshchapov V, Shishkina E. An approach to evaluation of strontium-90 spatial distribution in calcified biological samples using PCL method of digital autoradiography. In:

Proceedings of 54th Annual Meeting of the Health Physics Society, 12-16 July 2009b, Minneapolis, Minnesota, USA. http://hps.org/meetings/meeting8.html.

Napier BA, Degteva MO, Anspaugh LR, Shagina NB. Assessment of uncertainty in the radiation doses for the Techa River Dosimetry System. Chelyabinsk: Urals Research Center for Radiation Medicine; Status report for Milestone 23; 2009. 
Peremyslova LM, Tolstykh EI, Vorobiova MI, Degteva MO, Safronova NG, Shagina NB, Anspaugh LR, Napier BA. Analytical review of data available for the reconstruction of doses due to residence on the East Ural Radioactive Trace and the territory of windblown contamination from Lake Karachay. Chelyabinsk and Salt Lake City: Urals Research Center for Radiation Medicine and University of Utah; Final report for Milestone 10; September 2004.

Shagina NB, Tolstykh EI, Zalyapin VI, Degteva MO, Kozheurov VP, Tokareva EE, Anspaugh LR, Napier BA. Statistical analysis of repeated measurements of strontium-90 body burdens and evaluation of age- and sex- dependencies of strontium elimination rate during a period 25-45 years after intake. Chelyabinsk and Salt Lake City: Urals Research Center for Radiation Medicine and University of Utah; Progress report for Milestone 4; January 2002a.

Shagina NB, Tolstykh EI, Degteva MO, Kozheurov VP, Anspaugh LR, Napier BA. Update and improvements in a model for the biokinetics of strontium. Chelyabinsk and Salt Lake City: Urals Research Center for Radiation Medicine and University of Utah; Final report for Milestone 3, Part 2; April 2002b.

Shagina NB, Degteva MO, Tolstykh EI, Anspaugh LR, Napier BA. Dosimetric models for strontium in the human bone: A review of available data and researches needed. Chelyabinsk and Salt Lake City: Urals Research Center for Radiation Medicine and University of Utah; Unscheduled report; September 2005 (in Russian and English).

Shagina NB, Degteva MO, Tolstykh EI, Zalyapin VI, Krivoshchapov VA, Tokareva EE, Anspaugh LR, Napier BA. Algorithm for selection of the best individual estimate of internal dose on the basis of the results of calculations performed using three different protocols. Chelyabinsk and Salt Lake City: Urals Research Center for Radiation Medicine and University of Utah; Final report for Milestone 18; April 2007.

Shagina NB, Tolstykh EI, Harrison JD, Fell TP, Bolch WE, Degteva MO. Improved assessments of doses to the Techa River Offspring Cohort from maternal intakes of strontium-90. In: Late health effects of ionizing radiation: Bridging the experimental and epidemiologic divide conference, Washington DC, USA, May 4-6, 2009. Scientific programme and book of abstracts. Bethesda: National Cancer Institute; 2009:54.

Shishkina EA, Shved VA, Degteva MO, Tolstykh EI, Ivanov DV, Bayankin SN, Anspaugh LR, Napier BA, Wieser A, Jacob P. Description of the computer database "tooth" and discussion of requirements for EPR measurements to support a validation study of external doses calculated by use of the Techa River Dosimetry System-2000. Chelyabinsk and Salt Lake City: Urals Research Center for Radiation Medicine and University of Utah; Final report for Milestone 2; April 2001 (in Russian and English).

Shishkina EA, Shved VA, Tolstykh EI, Degteva MO, Anspaugh LR. Investigation of the tooth as a complex dosimeter: Formation of dose in tooth enamel. Chelyabinsk and Salt Lake City: Urals Research Center for Radiation Medicine and University of Utah; Unscheduled report; June 2002. 
Shishkina EA, Shved VA, Degteva MO, Tolstykh EI, Ivanov DV, Bayankin SN, Wieser A, Göksu HY, El-Faramawy NA, Semiochkina N, Jacob P, Anspaugh LR, Napier BA. Issues in the validation of external dose: Background and internal dose components of cumulative dose estimated using the EPR method. Chelyabinsk and Salt Lake City: Urals Research Center for Radiation Medicine and University of Utah; Final report for Milestone 7, Part 1; September 2003 (in Russian and English).

Tokareva EE, Degteva MO, Mikusheva RK, Schennikova VN, Shagina NB, Shved VA, Anspaugh LR, Napier BA. Description of the household registry for the Techa River settlements. Chelyabinsk and Salt Lake City: Urals Research Center for Radiation Medicine and University of Utah; Final report for Milestone 6; April 2003.

Tolstykh EI, Zalyapin VI, Krivoshchapov VA, Shagina NB, Peremyslova LM, Degteva MO, Kozheurov VP, Safronova NG, Anspaugh LR, Napier BA. Verification of referent-intake levels for strontium-90. Chelyabinsk and Salt Lake City: Urals Research Center for Radiation Medicine and University of Utah; Final report for Milestone 3 Part 1; September 2001 (in Russian and English).

Tolstykh EI, Zalyapin VI, Shagina NB, Krivoshchapov VA, Degteva MO, Tokareva EE, Anspaugh LR, Napier BA. Estimation of individual-to-model ratios (IMR) and their uncertainty for the Techa River residents. Chelyabinsk and Salt Lake City: Urals Research Center for Radiation Medicine and University of Utah; Final report for Milestone 4; November 2002 (in Russian and English).

Tolstykh EI, Zalyapin VI, Shagina NB, Krivoshchapov VA, Degteva MO, Tokareva EE, Anspaugh LR, Napier BA. Evaluation of ETRC subcohorts with different algorithms for 90Sr body burden estimation and assessment of their uncertainties. Chelyabinsk and Salt Lake City: Urals Research Center for Radiation Medicine and University of Utah; Final report for Milestone 8; September 2003 (in Russian and English).

Tolstykh EI, Shagina NB, Peremyslova LM, Degteva MO, Anspaugh LR, Napier BA. Methodological approaches to the reconstruction of radionuclide intake for residents of the East Urals Radioactive Trace and Karachay Trace. Chelyabinsk and Salt Lake City: Urals Research Center for Radiation Medicine and University of Utah; Final report for Milestones 11 and 12; April 2006.

Tolstykh EI, Shagina NB, Krivoshchapov VA, Degteva MO, Shishkina EA, Anspaugh LR, Napier BA. Improvement in strontium-90 reference intake function for residents of the Techa Riverside settlements. Chelyabinsk and Salt Lake City: Urals Research Center for Radiation Medicine and University of Utah; Unscheduled report; October 2008a.

Tolstykh EI, Shagina NB, Peremyslova LM, Safronova NG, Degteva MO, Anspaugh LR, Napier BA. Improvement in cesium-137 intake with milk contaminated as a result of soil $\rightarrow$ grass $\rightarrow$ milk transfer. Chelyabinsk and Salt Lake City: Urals Research Center for Radiation Medicine and University of Utah; Unscheduled report; October 2008b.

Vorobiova MI, Degteva MO, Tolstykh EI, Safronova NG, Peremyslova LM, Anspaugh LR, Napier BA. Verification and evaluation of uncertainties for intake levels for non-strontium radionuclides with use of an improved Techa River Model. Chelyabinsk and Salt Lake 
City: Urals Research Center for Radiation Medicine and University of Utah; Final report for Milestone 5; March 2003a.

Vorobiova MI, Degteva MO, Safronova NG, Kozyreva OV, Ivanov VM, Dimov GP, Romanskaya YuYu, Golikov VYu, Barkovsky AN, Anspaugh LR, Napier BA. Description of the $\mathrm{x}$-ray diagnostic procedures registry for the Techa River residents. Chelyabinsk and Salt Lake City: Urals Research Center for Radiation Medicine and University of Utah; Final report for Milestone 16; November 2003b (in Russian and English).

Vorobiova MI, Degteva MO, Peremyslova LM, Safronova NG, Shagina NB, Anspaugh LR, Napier BA. Methodological approaches to external dose reconstruction and validation for the EURT and 'Karachay trace' areas. Chelyabinsk and Salt Lake City: Urals Research Center for Radiation Medicine and University of Utah; Final report for Milestone 17; September 2006 (in Russian and English).

Vorobiova MI, Degteva MO, Safronova NG, Akhramenko BN, Anspaugh LR, Napier BA. Methodological approaches to evaluation of parameters for external exposure of the Techa River residents. Chelyabinsk and Salt Lake City: Urals Research Center for Radiation Medicine and University of Utah; Unscheduled report; October 2008. 
APPENDIX 1

UPDATED LIST OF PUBLICATIONS

FOR PROJECT 1.1 


\section{LIST OF PUBLICATIONS FOR PROJECT 1.1}

Note-The Russian dosimetrists receive funds from the U.S. Department of Energy (in prior years funds were also provided for Project 1.1 by the U.S. National Aeronautics and Space Administration and the U.S. Environmental Protection Agency) for 60\% support of their salary; the Federal Department of the Ministry of Health of the Russian Federation has provided through JCCRER Project 1.1 most of the remaining salary support. Some of the publications listed below have resulted from small, specific projects with a majority of funding from other sources; however, the work could not have been undertaken without the backbone support of JCCRER Project 1.1. The Russian Principal Investigator has managed effectively to combine the activities into a coherent project. In some cases the Russian dosimetrists of Project 1.1 have made the results of their work available to other projects without specific financial compensation, but the use of their results has been recognized through co-authorship of publications.

The total number of reports of various types are listed in Table 1.

Table 1. Numbers of reports of various types that have been published by investigators of Project 1.1.

\begin{tabular}{lccc}
\hline \multicolumn{1}{c}{ Type } & Total No. & No. in English & No. in Russian \\
\hline Articles in peer-reviewed journals & 89 & 68 & 27 \\
Other open literature publications & 187 & 102 & 117 \\
Milestone and other scientific reports & 41 & 41 & 30 \\
Progress reports and proposals & 30 & 30 & 0 \\
\hline
\end{tabular}

${ }^{a}$ Because some documents have been published in both languages, the sum of the papers in English and in Russian is greater than the total number of documents.

\section{ARTICLES IN PEER-REVIEWED JOURNALS}

Akleyev AV, Krestinina LY, Preston D, Davis F, Degteva MO, Anspaugh L, Startsev NV, Napier B, Ron E. Radiogenic risk of malignant neoplasms for Techa Riverside residents.

Med Radiol Radiat Saf 53:13-37; 2008 (in Russian).

Anspaugh LR, Degteva MO, Vasilenko EK. Mayak Production Association: Introduction.

Radiat Environ Biophys 41:19-22; 2002.

Anspaugh LR, Shishkina EA, Shved VA, Degteva MO, Tolstykh EI, Napier BA. Comment on

paper by Hayes, Haskell, and Kenner. Health Phys 85:622-624; 2003.

Anspaugh LR, Degteva MO, Vorobiova MI, Mokrov YuG, Napier BA. Dosimetry for members

of the Extended Techa River Cohort. Health Physics. 91(4):393-394; 2006.

Bauchinger M, Salassidis K, Braselmann H, Vozilova A, Pressl S, Stephan G, Snigiryova G, Kozheurov VP, Akleyev A. FISH-based analysis of stable translocations in a Techa River population. Intl J Radiat Biol 73:605-612; 1998.

\footnotetext{
* Other sources have included the Commission of European Communities, the International Science and Technology Center, and the International Science Foundation.
} 
Bougrov NG, Göksu HY, Haskell E, Degteva MO, Meckbach R, Jacob P. Issues in the reconstruction of environmental doses on the basis of thermoluminescence measurements in the Techa Riverside. Health Phys 75:574-583; 1998.

Bougrov NG, Degteva MO, Göksu HY, Meckbach R, Jacob P. Retrospective thermoluminescence dosimetry in the riverside territories of the upper-Techa River. Radiat Safety Problems (Mayak Production Association Scientific Journal) № 3:51-62; 2001 (in Russian).

Bougrov NG, Baturin VA, Göksu HY, Degteva MO, Jacob P. Investigation of thermoluminescence dosimetry in the Techa River flood plain: Analysis of the new results. Radiat Prot Dosim 101:225-228; 2002.

Bugrov NG, Degteva MO, Arshansky SM. Modernized whole-body counter SICH-9.1M for in vivo measurements of $90 \mathrm{Sr}$ and $137 \mathrm{Cs}$ body burden. Medicine of Extreme Situations (Scientific and Practical Journal of Medical-Biological Agency of RF) №4(26):78-86; 2008 (in Russian).

Degteva MO, Kozheurov VP, Burmistrov DS, Vorobyova MI, Valchuk VV, Bougrov NG, Shishkina HA. An approach to dose reconstruction for the Urals population. Health Phys 71:71-76; 1996.

Bougrov NG, Degteva MO, Vorobiova MI, Jacob P, Göksu Y. Assessment of anthropogenic dose distribution in Metlino village reconstructed using luminescence methods. Radiat Safety Problems (Mayak Production Association Scientific Journal) №3:33-47; 2009 (in Russian).

Degteva MO, Kozheurov VP, Tolstykh EI. Retrospective dosimetry related to chronic environmental exposure. Radiat Prot Dosim 79:155-160; 1998.

Degteva MO, Vorobiova MI, Kozheurov VP, Tolstykh EI, Anspaugh LR, Napier BA. Dose reconstruction system for the exposed population living along the Techa River. Health Phys 78:542-554; 2000.

Degteva MO, Kozheurov VP, Tolstykh EI, Vorobiova MI, Anspaugh LR, Napier BA, Kovtun AN. The Techa River Dosimetry System: Methods for the reconstruction of internal dose. Health Phys 79:24-35; 2000.

Degteva MO, Vorobiova MI, Tolstykh EI, Shagina NB, Anspaugh LR, Napier BA. Dosimetry of the Techa River System: Dose reconstruction for radiation consequences risk assessment. Radiat Safety Problems (Mayak Production Association Scientific Journal) № 4:36-46; 2000 (in Russian).

Degteva MO, Tolstykh EI, Vorobiova MI, Shagina NB, Kozheurov VP, Anspaugh LR, Napier BA. Improving the dose reconstruction system for estimating the risk of late effects in the Techa River population. Med Radiol Radiat Saf 46:9-21; 2001 (in Russian).

Degteva MO, Shagina NB, Tolstykh EI, Vorobiova MI, Napier BA, Anspaugh LR. Studies on the Techa River populations: Dosimetry. Radiat Environ Biophys 41:41-44; 2002.

Degteva MO, Tolstykh EI, Vorobiova MI. Assessment of doses to the offspring of the Techa River Cohort due to intakes of radionuclides by the mother. Radiat Prot Dosim 105:609$614 ; 2003$.

Degteva MO, Anspaugh LR, Akleyev AV, Jacob P, Ivanov DV, Weiser A, Vorobiova MI, Shishkina EA, Shved VA, Vozilova AV, Bayankin SN, Napier B. Electron paramagnetic resonance and fluorescence in situ hybridization-based investigations of individual doses 
for persons living at Metlino in the upper reaches of the Techa River. Health Phys 88:139$153 ; 2005$.

Degteva MO, Tolstykh EI, Vorobiova MI, Shagina NB, Shishkina EA, Bougrov NG, Anspaugh LR, Napier BA. Techa River Dosimetry System: Current status and future. Radiat Safety Problems (Mayak Production Association Scientific Journal) № 1:66-80; 2006 (in Russian).

Degteva MO, Vorobiova MI, Tolstykh EI, Shagina NB, Shishkina EA, Anspaugh LR, Napier BA, Bougrov NG, Shved VA, Tokareva EE. Development of an improved dose reconstruction system for the Techa River population affected by the operation of the Mayak Production Association. Radiat Res 166:255-270; 2006.

Degteva MO, Shagina NB, Tolstykh EI, Bougrov NG, Zalyapin VI, Anspaugh LR, Napier BA. An approach to reduction of uncertainties in internal doses reconstructed for the Techa River population. Radiat Prot Dosim 127:480-485; 2007.

Degteva MO, Bougrov NG, Vorobiova MI, Jacob P, Göksu HY. Evaluation of anthropogenic dose distribution amongst building walls at the Metlino area of the upper Techa River region. Radiat Environ Biophys 47:469-479; 2008.

Glagolenko YV, Drozhko EG, Mokrov YG, Rovny SI, Stukalov PM, Ivanov IA, Alexakhin AI, Vorobiova MI, Degteva MO, Akleyev AV. Reconstruction of parameters of the source of liquid radioactive waste discharges from the radiochemical plant into the Techa River. Report 1: Development of methods, main results. Radiat Safety Problems (Mayak Production Association Scientific Journal), Special Issue 2008:76-91 (in Russian) 72-86 (in English); 2008.

Göksu HY, Heide LM, Bougrov NG, Dalheimer AR, Meckbach R, Jacob P. Depth-dose distribution in bricks determined by thermoluminescence and by Monte-Carlo calculation for external $\gamma$-dose reconstruction. Appl Radiat Isot 47:433-440; 1996.

Göksu HY, Degteva MO, Bougrov NG, Meckbach R, Haskell EH, Bailiff IK, Bøtter-Jensen L, Jungner H, Jacob P. First international intercomparison of luminescence techniques using samples from the Techa River Valley. Health Phys 82:94-102; 2002.

Göksu HY, Semiochkina N, Shishkina EA, Wieser A., El-Faramawy NA, Degteva MO, Jacob P, Ivanov DV. Thin layer $\alpha-\mathrm{A} 12 \mathrm{O} 3: \mathrm{C}$ beta dosemeters for the assessment of current dose rate in teeth due to $90 \mathrm{Sr}$ intake and comparison with electron paramagnetic resonance dosimetry. Radiat Prot Dosim 101:507-513; 2002.

Haskell EH, Hayes RB, Romanyukha AA, Kenner GH. Preliminary report on the development of a virtually non-destructive additive dose technique for EPR dosimetry. Appl Radiat Isot 52:1065-1070; 2000.

Jacob P, Göksu Y, Taranenko V, Meckbach R, Bougrov NG, Degteva MO, Vorobiova MI. On an evaluation of external dose values in the Techa River Dosimetry System (TRDS) 2000. Radiat Environ Biophys 42:169-174; 2003.

Khokhryakov VV, Drozhko EG, Glagolenko YV, Rovny SI, Vasilenko EK, Suslov A, Anspaugh LR, Napier BA, Bouville A, Khokhryakov VF, Suslova KG, Romanov SA. Studies on the Ozyorsk population: Dosimetry. Radiat Environ Biophys 41:33-35; 2002.

Koshta AA, Wieser A, Ignatiev EA, Bayankin S, Romanyukha A, Degteva MO. New computer procedure for routine EPR-dosimetry on tooth enamel: Description and verification. Appl Radiat Isot 52:1287-1290; 2000. 
Kossenko MM, Degteva MO, Vyushkova OV, Preston DL, Mabuchi K, Kozheurov VP. Issues in the comparison of risk estimates for the population in the Techa River Region and atomic bomb survivors. Radiat Res 148:54-63; 1997.

Kossenko MM, Akleyev AV, Startsev NV, Degteva MO. Epidemiological analysis of remote cancerogenesis effects on populations with chronic exposure to radiation in the Urals Region. Intl J Radiat Med 2:34-41; 1999 (in English and Russian)

Kossenko MM, Ostroumova Y, Akleyev A, Startsev N, Degteva M, Granath F, Hall P. Mortality in the offspring of individuals living along the radioactively contaminated Techa River: A descriptive analysis. Radiat Environ Biophys 39:219-225; 2000.

Kossenko MM, Preston DL, Krestinina LY, Degteva MO, Startsev NV, Thomas T, Vyushkova OV, Anspaugh LR, Napier BA, Kozheurov VP, Ron E, Akleyev AV. Studies on the Extended Techa River Cohort: Cancer risk estimation. Radiat Environ Biophys 41:45-48; 2002.

Kovtun AN, Puzikov AG, Sokolov IA, Kozheurov VP, Degteva MO. Anthropomorphic phantom with strontium-90 incorporated in the skeleton. Radiat Prot Dosim 89:302-304; 2000.

Kozheurov VP, Zalyapin VI, Shagina NB, Tokareva EE, Degteva MO, Tolstykh EI, Anspaugh LR, Napier BA. Evaluation of uncertainties in the 90Sr-body-burdens obtained by wholebody count: Application of Bayes' rule to derive detection limits by analysis of a posteriori data. Appl Radiat Isot 57:525-535; 2002.

Krestinina LYu, Preston DL, Ostroumova EV, Degteva MO, Ron E, Vyushkova OV, Startsev NV, Kossenko MM, Akleyev AV. Protracted radiation exposure and cancer mortality in the Techa River Cohort. Radiat Res 164:602-611; 2005.

Krestinina LYu, Preston DL, Ostroumova EV, Degteva MO, Ron E, Vyushkova OV, Startsev NV, Kossenko MM, Akleyev AV. Reply to Comments on "Protracted radiation exposure and cancer mortality in the Techa River Cohort." Radiat Res 166:814-815; 2006.

Krestinina EYu, Davis F, Ostroumova EV, Epifanova SB, Degteva MO, Preston DL, Akleyev AV. Solid cancer incidence and low-dose-rate radiation exposures in the Techa River cohort: 1956-2002. Intl J Epidemiol 36:1038-1046; 2007.

Levina SG, Shagina NB, Akleyev AV, Zakharov SG, Shibkova DZ, Deryagin VV, Udachin VN, Popova IY, Zemerova ZP. Some regularities in the behavior of radionuclides in water of the lakes situated on the East-Urals Radioactive Trace. Radiat Biol Radioecol 48:616-626; 2008 (in Russian).

Napier BA, Shagina NB, Degteva MO, Tolstykh EI, Vorobiova MI, Anspaugh LR. Preliminary uncertainty analysis for the doses estimated using the Techa River Dosimetry System 2000. Health Phys 81:395-405; 2001.

Pafundi D, Lee C, Watchman C, Bourke V, Aris J, Shagina N, Harrison J, Fell T, Bolch W. An image-based skeletal tissue model for the ICRP reference newborn. Phys Med Biol 54:4497-4531; 2009.

Peremyslova LM, Kostyuchenko VA, Degteva MO, Baturin VA, Popova IYa, Akleyev AV. The usage of current population exposure dose for justification of EURT area rehabilitation. Radiat Safety Problems (Mayak Production Association Scientific Journal) № 2:50-54; 2001 (in Russian).

Phipps AW, Tolstykh EI, Shagina NB, Harrison JD, Degteva MO. The application and adaptation of ICRP internal dosimetry models to the calculation of bone marrow tissue 
doses from ${ }^{90} \mathrm{Sr}$ for epidemiological studies of Techa River population. Radiat Biol Radioecol 46:647-656; 2006.

Romanyukha AA, Degteva MO, Kozheurov VP, Wieser A, Jacob P, Ignatiev EA, Vorobiova MI. Pilot study of the Urals population by tooth electron paramagnetic resonance dosimetry. Radiat Environ Biophys 35:305-310; 1996.

Romanyukha AA, Ignatiev EA, Degteva MO, Kozheurov VP, Wieser A, Jacob P. Radiation doses from Ural region. Nature 381:199-200; 1996.

Romanyukha AA, Hayes RB, Haskell EH, Kenner GH. Geographic variations in the structure of the EPR spectrum of irradiated tooth enamel. Radiat Prot Dosim 84:445-450; 1999.

Romanyukha AA, Seltzer SM, Desrosiers M, Ignatiev EA, Ivanov DV, Bayankin S, Degteva MO, Eichmiller FC, Wieser A, Jacob P. Correction factors in the EPR dose reconstruction for residents of the middle and lower Techa Riverside. Health Phys 81:554-566; 2001.

Romanyukha AA, Mitch MG, Lin Z, Nagy V, Coursey M. Mapping the distribution of 90Sr in teeth with a photostimulable phosphor imaging detector. Radiat Res 157:341-349; 2002.

Shagina NB, Tolstykh EI, Zalyapin VI, Degteva MO, Kozheurov VP, Tokareva EE, Anspaugh LR, Napier BA. Evaluation of age and gender dependences of the rate of strontium elimination 25-45 years after intake: Analysis of data from residents living along the Techa River. Radiat Res 159:239-246; 2003.

Shagina NB, Tolstykh EI, Degteva MO. Improvements in the biokinetic model for strontium with allowance for age and gender differences in bone mineral metabolism. Radiat Prot Dosim 105:619-622; 2003.

Shagina NB, Bougrov NG, Degteva MO, Kozheurov VP, Tolstykh EI. An application of in vivo whole body counting technique for studying strontium metabolism and internal dose reconstruction for the Techa River population. Journal of Physics: Conference Series 41:433-440; 2006.

Shagina NB, Degteva MO, Tolstykh EI, Zalyapin VI, Anspaugh LR, Napier BA. Reduction of the uncertainties of the internal doses due to strontium-90 for the Extended Techa River Cohort. Radiat Safety Problems (Mayak Production Association Scientific Journal) Special issue 1:5-25; 2006 (in Russian).

Shagina NB, Tolstykh EI, Fell TP, Harrison JD, Phipps AW, Degteva MO. In utero and postnatal haemopoietic tissue doses resulting from maternal ingestion of strontium isotopes from the Techa river. Radiat Prot Dosim 127:497-501; 2007.

Shibkova DZ, Efimova NV, Tolstykh EI, Andreeva OG. Compensatory adjustment of hemopoietic stem cell pool of CBA mice after acute intake of 90Sr. Radiat Biol Radioecol 45:180-190; 2005 (in Russian).

Shishkina EA, Lyubashevskii NM, Tolstykh EI, Ignatiev EA, Betenekova TA, Nikiforov SV. A mathematical model for calculation of $90 \mathrm{Sr}$ absorbed dose in dental tissues: Elaboration and comparison to EPR measurements. Appl Radiat Isot 55:363-374; 2001.

Shishkina EA, Degteva MO, Shved VA, Ivanov DV, Bayankin SN, Knyazev VA, Vasilenko EK, Smetanin MY, Gorelov MV. Problems and prospects of EPR researches in the Southern Urals. Radiat Safety Problems (Mayak Production Association Scientific Journal) № 2:59-70; 2003 (in Russian).

Shishkina EA, Göksu HY, El-Faramawy NA; Semiochkina N. Assessment of 90Sr concentration in dental tissue using thin-layer beta-particle detectors and verification with numerical calculations. Radiat Res 163:462-467; 2005. 
Shishkina EA, Degteva MO, Tolstykh EI, Shved VA, Tokareva EE, Ivanov DV, Bayankin SN, Wieser A, Göksu HY, Anspaugh LR. Results of tooth dosimetric investigations for residents of the Techa Riverside region. Radiat Safety Problems (Mayak Production Association Scientific Journal) Special issue1:26-44; 2006 (in Russian).

Straume T, Anspaugh LR, Haskell EH, Lucas JN, Marchetti AA, Likhtarev IA, Chumak VV, Romanyukha AA, Khrouch VT, Gavrilin YuI, Minenko VA. Emerging technological bases for retrospective dosimetry. Stem Cells 15(Suppl.):183-193; 1997.

Taranenko V, Meckbach R, Degteva MO, Bougrov NG, Göksu Y, Vorobiova MI, Jacob P. Verification of external exposure assessment for the Upper Techa Riverside by luminescence measurements and Monte Carlo photon transport modeling. Radiat Environ Biophys 42:17-26; 2003.

Tikunov DD, Ivannikov AI, Shishkina EA, Petin DV, Borysheva NB, Orlenko S, Nalapko M, Shved VA, Skvortsov VG, Stepanenko VF. Complex experimental research on internal tooth dosimetry for the Techa River region: A model for $90 \mathrm{Sr}$ accumulation in human teeth formed by time of intakes. Radiat Meas 41:565-576; 2006.

Tolstykh EI, Kozheurov VP, Vyushkova OV, Degteva MO. Analysis of strontium metabolism in humans on the basis of the Techa River data. Radiat Environ Biophys 36:25-29; 1997.

Tolstykh EI, Degteva MO, Kozheurov VP, Burmistrov DS. Strontium transfer from maternal skeleton to the fetus estimated on the basis of the Techa River data. Radiat Prot Dosim 79:307-310; 1998.

Tolstykh EI, Degteva MO, Kozheurov VP, Shishkina EA, Romanyukha AA, Wieser A, Jacob P. Strontium metabolism in teeth and enamel dose assessment: Analysis of the Techa River data. Radiat Environ Biophys 39:161-171; 2000.

Tolstykh EI, Degteva MO, Shagina NB, Kozheurov VP, Repin VS, Novak NYu, Berkovski V, Noßke D. Biokinetic models for strontium: Estimation of reliability for the late period after intake. Intl J Radiat Med 3:133 (in English) and 301 (in Russian); 2001.

Tolstykh EI, Degteva MO, Peremislova LM, Vorobiova MI, Kozheurov VP. Dietary intake and 90Sr contents in the residents of the East Urals Radioactive Trace. Forty-year study experience. Intl J Radiat Med 3:134 (in English) and 300 (in Russian); 2001.

Tolstykh EI, Degteva MO, Vorobiova MI, Kozheurov VP. Fetal dose assessment for the offspring of the Techa Riverside residents. Radiat Environ Biophys 40:279-286; 2001.

Tolstykh EI, Degteva MO, Vorobiova MI, Kozheurov VP, Peremislova LM. Dietary intake and 90Sr body contents in the residents of the Eastern Urals Radioactive Trace. Experience in the forty-year monitoring. Intl J Radiat Med 4:127-133; 2002 (in English and Russian).

Tolstykh EI, Degteva MO, Shagina NB, Kozheurov VP, Repin VS, Berkovski V, Noßke D. Biokinetic models for strontium: Estimation of reliability for late period after intake. Intl $\mathrm{J}$ Radiat Med 4:134-143; 2002 (in English and Russian).

Tolstykh EI, Shishkina EA, Degteva MO, Ivanov DV, Bayankin SN, Anspaugh LR, Napier BA, Wieser A, Jacob P. Age dependencies of 90Sr incorporation in dental tissues:

Comparative analysis and interpretation of different kinds of measurements obtained for residents on the Techa River. Health Phys 85:409-419; 2003.

Tolstykh EI, Tokareva EE, Peremyslova LM, Degteva MO. Mineral content in different bones of the skeleton of Urals residents as a function of gender and age. Morphol 125:72-75; 2004 (in Russian). 
Tolstykh EI, Peremyslova LM, Shagina NB, Degteva MO, Vorobiova MI, Tokareva EE, Safronova NG. Characteristics of 90Sr accumulation and elimination for residents of the Urals region in 1957-1988. Radiat Biol Radioecol 45:495-504; 2005 (in Russian).

Tolstykh EI, Degteva MO, Peremyslova LM, Shagina NB, Zalyapin VI, Krivoschapov VA, Anspaugh LR, Napier BA. Reconstruction of long-lived radionuclide intakes for Techa Riverside residents. Part 1. Strontium-90. Radiat Safety Problems (Mayak Production Association Scientific Journal) Special issue 1:45-67; 2006 (in Russian).

Tolstykh EI, Degteva MO, Vorobiova MI, Peremyslova LM, Shagina NB, Anspaugh LR, Napier BA. Reconstruction of long-lived radionuclide intakes for Techa Riverside residents. Part 2. Cesium-137. Radiat Safety Problems (Mayak Production Association Scientific Journal) Special issue 1:68-79; 2006 (in Russian).

Tolstykh EI, Degteva MO, Shishkina EA, Zalyapin VI, Krivoschapov VA. Possibility of using human teeth for retrospective dosimetry: Analysis of the Techa river data. Radiat Prot Dosim 127:511-515; 2007.

Tolstykh EI, Shagina NB, Peremyslova LM, Degteva MO, Phipps AW, Harrison JD, Fell TP. Reconstruction of 90Sr intake for breast-fed infants in the Techa Riverside settlements. Radiat Environ Biophys 47:349-357; 2008.

Tolstykh EI. Shagina NB, Peremyslova LM, Degteva MO. Secular trend in bone mineral content in humans: Analysis of data from the Ural region. Morphol 2009 (in Russian) - in press.

Trapeznikov AV, Molchanova IV, Karavaeva EN, Peremyslova LM, Mikhajlovskaya LN, Popova IYa, Nikolkin VN, Vorobiova MI, Trapeznikova VN, Kostychenko VA, Korzhavin AV. Results of long-term radioecological studies of the Techa River. Radiat Safety Problems (Mayak Production Association Scientific Journal) 3:36-49; 2007 (in Russian).

Veronese I, Shved V, Shishkina EA, Giussani A, Göksu HY. Study of dose rate profile at sample disks in a Risø OSL single-grain attachment system. Radiat Meas 42:138-143; 2007.

Veronese I, Fattibene P, Cantone MC, De Coste V, Giussani A, Onori S, Shishkina EA. EPR and TL-based beta dosimetry measurements in various tooth components contaminated by 90Sr. Radiat Meas 43:813-818; 2008.

Vorobiova MI, Degteva MO, Burmistrov DS, Safronova NG, Kozheurov VP, Anspaugh LR, Napier BA. Review of historical monitoring data on Techa River contamination. Health Phys 76:605-618; 1999.

Vorobiova MI, Degteva MO. Simple model for the reconstruction of radionuclide concentrations and radiation exposures along the Techa River. Health Phys 77:142-149; 1999.

Wieser A, Romanyukha AA, Degteva MO, Kozheurov VP, Petzold, G. Tooth enamel as a natural beta dosemeter for bone seeking radionuclides. Radiat Prot Dosim 65:413-416; 1996.

Wieser A, Fattibene P, Shishkina EA, Ivanov DV, De Coste V, Guttler A, Onori S. Assessment of performance parameters for EPR dosimetry with tooth enamel. Radiat Meas 43:731736; 2008.

Zalyapin VI, Krivoshchapov VA. Numerical analysis of one inverse problem of applied biophysics. Bull. Southern Urals State University, Series 2 on Mathematics, Physics, and Chemistry № 3:3-11; 2002 (in Russian). 
Zalyapin VI, Krivoshchapov VA, Degteva MO. Numerical analysis of an applied biophysics inverse problem. Inverse Prob Science Engin 12:379-392; 2004.

Zalyapin VI, Shishkina EA, Fattibene P, Wieser A, Ivanov DV, Degteva MO. Statistical analysis of the EPR measurements. Bull Southern Urals State University, Series 2 on Mathematical Modeling and Programming №27(127):36-44; 2008 (in Russian).

\section{OTHER OPEN LITERATURE PUBLICATIONS}

Akleyev AV, Awa A, Akiyama M, Veremeeva GA, Vozilova AV, Nakamura N, Kodama N, Nanako M, Ohtaki K, Kioizumi S, Kozheurov VP. Biological indication of chronic exposure in late period. In: Chronic radiation exposure: Risk of late effects. Moscow: Izdat; 1996(1):7-19 (in Russian).

Akleyev AV, Krestinina LYu, Kostyuchenko VA, Degteva MO, Startsev NV. Prerequisites for epidemiological analyses of the East Urals Radioactive Trace. In: Workshop on radiation risk research in Southern Urals, book of abstracts. Neuherberg: GSF-National Research Center for Environment and Health; 2002.

Anspaugh LR. An overview of dose reconstruction: Lessons learned from studies in the United States. In: Assessing health and environmental risks from long-term radiation contamination in Chelyabinsk, Russia. Washington: American Association for the Advancement of Science; 1997:3-19.

Anspaugh LR, Akleyev AV, Degteva MO, Straume T, Napier BA. Interpretation of results of FISH assays when zero or only a few translocations are observed. In: Chronic radiation exposure: Possibilities of biological indication. Chelyabinsk: Urals Research Center for Radiation Medicine; 2000:111-112 (in Russian and English).

Bayankin SN, Ivanov DV, Shishkina EA, Shved VA.. Study of angle-dependence of radiation interaction of electrons with biological hydroxyapatite. In: Book of abstracts for the Xth international symposium, 'Ural Atomic, Ural Industrial.' Ekaterinburg: Institute of Industrial Ecology; 2002:15-16, 2002 (in Russian).

Bayankin SN, Ivanov DV, Shishkina EA. An evaluation of the possibility to use incisor's enamel for retrospective dosimetry by electron paramagnetic resonance method. In Proceedings of the XIth international symposium, 'Ural Atomic, Ural Industrial,' Ekaterinburg, Russia, February 7-11, 2005. Ekaterinburg: Institute of Industrial Ecology; 2005:8-10 (in Russian).

Bougrov NG. Assessment of the external gamma-doses on the Techa River Valley area using thermoluminescence method. In: Problems of ecology and ecological education in the Chelyabinsk Region. Chelyabinsk: Chelyabinsk State Pedagogical University; 1999:9599 (in Russian).

Bougrov NG. Use of the thermoluminescence method for the reconstruction of gamma-radiation dose from contaminated reservoirs. Moscow: Moscow Biophysics Institute; Doctoral thesis; 1999 (in Russian).

Bougrov NG, Baturin VA, Göksu HY, Degteva M. External gamma-dose reconstruction in the upper Techa River: The new results of thermoluminescence investigations. In: Chronic 
radiation exposure: Possibilities of biological indication. Chelyabinsk: Urals Research Center for Radiation Medicine; 2000:177-178 (in Russian and English).

Bougrov NG, Baturin VA, Goeksu HY, Degteva MO. Investigations of thermoluminescence dosimetry in the Techa River floodplain: Analysis of the new results. In: The 13th international conference on solid state dosimetry, 9-13 July 2001, Athens, Greece, Program and Abstracts. Tel Aviv: International Solid State Dosimetry Organization; 2001:173.

Bougrov, N.G.; Degteva, M.O.; Göksu, H.Y.; Bailiff, I.K.; Bøtter-Jensen, L.; Jacob, P. First international intercomparison of luminescence techniques using samples from the Techa River Valley. In: Proceedings of the First Regional Conference on "Adaptation of biological systems to natural and extreme conditions." Chelyabinsk: State Pedagogical University; 2001:89-94 (in Russian).

Bougrov NG, Tolstykh EI, Degteva MO, Shagina NB, Kozheurov VP, Tokareva EE, Mikusheva RK, Kuzina TV. Long-term monitoring of long-lived radionuclide body burdens for the population of the Urals region. In: Proceedings of the scientific conference on "Actual problems of radiation hygiene," St. Petersburg, Russia, June 21-25, 2004. St. Petersburg: Research Institute for Radiation Medicine; 2004:66-68 (in Russian).

Bougrov NG, Farafontov VG. Whole body counter upgrade as a way to improve reliability of monitoring data on radionuclides body burden for residents of the Urals region. In: Proceedings of all-Russian scientific conference on "Adaptation of biological systems to natural and extreme conditions." Chelyabinsk: State Pedagogical University; 2004:166171 (in Russian).

Bougrov NG, Ulanovsky AV, Woda K. Radiation monitoring and sampling approaches for retrospective dosimetry using luminescence methods at the Techa River. In: Proceedings of the first international scientific conference on "Adaptation of biological systems to natural and extreme conditions," Chelyabinsk, Russia, October 9-11, 2006. Chelyabinsk: State Pedagogical University; 2006:7-11 (in Russian).

Bougrov NG. Uncertainty in radionuclide body-burden measurements performed with SICH9.1M whole-body counter: Role of anthropometric parameters. In: Proceedings of the $2^{\text {nd }}$ international scientific conference on "Adaptation of biological systems to natural and extreme conditions," Chelyabinsk, Russia. Chelyabinsk: State Pedagogical University; Vol. 1:3-5; 2008 (in Russian).

Burmistrov DS, Kozheurov VP, Vorobiova MI. Elaboration of system of retrospective dose estimation for external irradiation of the Techa Riverside residents. In: Chronic radiation exposure: Risk of late effects. Chelyabinsk: Urals Research Center for Radiation Medicine; 1995:68-69 (in Russian) 138 (in English).

Burmistrov DS, Vorobiova MI, Degteva MO, Linkov I, Wilson R. Radioactive contamination of the Techa River: Environmental records and multimedia modelling. In: Nuclear data for science and technology, Proceedings of an international conference. Bologna: Societa Italiana di Fisica II:1376-1380; 1997.

Burmistrov D, Taranenko V, Linkov I. Dynamic modeling of radionuclides fate and transport in the Techa River and its application for dose reconstruction. In: Proceedings of the fourth international symposium and exhibition on environmental contamination in Central and Eastern Europe; September 15-17, 1998, Warsaw, Poland. 
Chuvakova D, Suvorova AV, Shishkina EA. Age-specific changes in dimensions of the first low incisors for rural residents of the Urals. In: Proceedings of the $2^{\text {nd }}$ international scientific conference on "Adaptation of biological systems to natural and extreme conditions", Chelyabinsk, Russia. Chelyabinsk: State Pedagogical University; Vol. 1:15-20; 2006 (in Russian).

Degteva MO. Environmental dose reconstruction for the Urals population. In: Environmental dose reconstruction and risk implications. Bethesda: National Council on Radiation Protection and Measurements; Proceedings No. 17; 1996:155-170.

Degteva MO. Methodical basis of population dose reconstruction for the population of the Techa riverside. In: Techa-99: Social and radiation protection of population, remediation of territory. Chelyabinsk: Chelyabinsk Regional Administration; 1999:8-25 (in Russian).

Degteva MO, Vyushkova OV, Khristevich NP, Kozheurov VP, Dukhovny IR, Kozyrev AV, Koscheev LN. Data management system for the follow-up of exposed population in the Urals. In: Chronic radiation exposure: Risk of late effects. Chelyabinsk: Urals Research Center for Radiation Medicine; 1995:67 (in Russian) 137 (in English).

Degteva MO, Kozheurov VP, Tolstykh EI, Kovtun AN. The measuring and modelling of strontium-90: An integrated retrospective dosimetry issue. In: Proceedings 1996 international congress on radiation protection. Seibersdorf: International Radiation Protection Association; ISBN 3-9500255-4-5; 1996, Vol. 1:417-424.

Degteva MO, Kozheurov VP, Vorobiova MI, Burmistrov DS, Khokhryakov VV, Suslova KG, Anspaugh LR, Napier BA, Bouville A. Population exposure dose reconstruction for the Urals region. In: Assessing health and environmental risks from long-term radiation contamination in Chelyabinsk, Russia. Washington: American Association for the Advancement of Science; 1997:21-33.

Degteva MO, Vassilenko EK, Romanyukha AA. Retrospective dosimetry for occupational and environmental exposure. In: Large scale area remediation, abstracts of the 2nd ISTC/SAC seminar. Snezhinsk: Russian Federal Nuclear Center - All-Russian Institute of Technical Physics; 1999:35-36 (in Russian and English).

Degteva MO, Kozheurov VP, Tolstykh EI, Vorobiova MI, Anspaugh LR, Napier BA. The Techa River Dosimetry System: Dose reconstruction for population risk analysis. In: Harmonization of radiation, human life and the ecosystem, Proceedings of 10th international congress on radiation protection. Hiroshima: International Radiation Protection Association; CD-ROM; Paper No. T-19(1)-4; 2000.

Degteva MO, Jacob P, Vorobiova MI, Bougrov NG, Akleyev AV, Romanyukha AA, Wieser A, Meckbach R, Göksu HY, Taranenko VA. Comparative analysis of methods used in external dose reconstruction for the Techa River population. In: Chronic radiation exposure: Possibilities of biological indication. Chelyabinsk: Urals Research Center for Radiation Medicine; 2000:176-177 (in Russian and English).

Degteva MO, Kozheurov VP, Vorobiova MI, Tolstykh EI. Exposure doses received by the population of the Techa Riverside villages. In: Medical-biological and ecological impacts of radioactive contamination of the Techa River. Moscow: Federal Department of the Ministry of Health of the Russian Federation; 2000:128-158 (in Russian).

Degteva MO, Kozheurov VP, Tolstykh EI, Vorobiova MI, Anspaugh LR, Napier BA.

Evaluation of the stochastic effects of low-dose radiation: Dose reconstruction for the 
Techa River Cohort in Russia. In: Abstract volume, bioastronautics investigators' workshop. Houston: Universities Space Research Association; 2001:290-291.

Degteva M, Anspaugh L, Napier B, Bell R. Dose reconstruction validation and epidemiological studies for the Russian Extended Techa River Cohort. Health Phys 82:S163-S164; 2002.

Degteva MO, Tolstykh EI. Assessment of doses to the offspring of the Techa River Cohort due to intakes of radionuclides by the mother. In: Scientific programme abstracts for the workshop on internal dosimetry of radionuclides. Occupational, public and medical exposure. Oxford: National Radiological Protection Board; Session 13; 2002.

Degteva MO, Vorobiova MI, Tolstykh EI, Anspaugh LR, Napier BA. Dose-reconstruction system for the Extended Techa River Cohort. Health Phys 86:S174; 2004.

Degteva MO. Methodological basis of dose reconstruction for population of the Urals region: Quality assurance of dosimetric models. In: Proceedings of the XI international symposium, 'Ural Atomic, Ural Industrial,' Ekaterinburg, Russia, February 7-11, 2005. Ekaterinburg: Institute of Industrial Ecology; 2005:27-30 (in Russian and English).

Degteva MO, Tolstykh EI, Vorobiova MI, Anspaugh LR, Napier BA. Techa River Dosimetry System: Current status and future. In: III International symposium, 'Chronic radiation exposure: Biological and health effects,' book of abstracts. Chelyabinsk: Urals Research Center for Radiation Medicine 2005:91 (in English) 104 (in Russian).

Degteva MO, Vorobiova MI, Shagina NB, Anspaugh LR, Napier BA. A review of data on releases of radioactive wastes from the "Mayak" Production Association into the Techa River in 1949-1956. In: Medical-Biological Effects of Chronic Radiation Exposure. Chelyabinsk: Fregat; 2005:263-304 (in Russian).

Degteva MO, Anspaugh LR, Jacob P, Akleyev AV, Ivanov DV, Shishkina EA, Bougrov NG, Vorobiova MI, Vozilova AV, Shved VA, Wieser A, Taranenko VA, Göksu HY, Meckbach $\mathrm{R}$, Bayankin SN. Retrospective dosimetry for environmental exposure: Results of studies performed on the Techa River. In: Medical-Biological Effects of Chronic Radiation Exposure. Chelyabinsk: Fregat; 2005:305-360 (in Russian).

Degteva MO, Shagina NB, Tolstykh EI, Zalyapin VI, Anspaugh LR, Napier BA. An approach to reduction of uncertainties in internal doses reconstructed for the Techa River population. In: Internal dosimetry of radionuclides: Occupational, public and medical exposure; Book of abstracts. Paris: IRSN/HPA; 2006:155.

Degteva MO, Vorobiova MI, Golikov VYu, Barkovsky AN. On the question of needs and possibilities of the reconstruction of individual doses of medical exposure for the Techa River residents. In: Proceedings of the first international scientific conference on "Adaptation of biological systems to natural and extreme conditions," Chelyabinsk, Russia, October 9-11, 2006. Chelyabinsk: State Pedagogical University; 2006:17-21 (in Russian).

Degteva MO, Tolstykh EI, Shagina NB, Bugrov NG, Shishkina EA, Vorobiova MI. Problems of individual dosimetry on the Techa River. In: Medical and ecological effects of ionizing radiation (MEEIR-IV). Proceedings of IV International scientific-practical conference. Tomsk: Seversk Biophysics Research Center; 2007:154 (in Russian).

Degteva MO, Tolstykh EI, Vorobiova MI, Shagina NB, Anspaugh LR, Napier BA. Possible impact of confounding sources of environmental exposure for the members of the Techa River cohorts. In: Fifth international workshop on radiation risk research in Southern Urals. Scientific Programme and Book of Abstracts. Neuherberg: GSF-National Research Center for Environment and Health; 2007:33. 
Degteva MO, Tolstykh EI, Vorobiova MI, Shagina NB, Anspaugh LR, Napier BA. Structure of a new Techa River Dosimetry System: General approach and evaluation of parameters. In: Late health effects of ionizing radiation: Bridging the experimental and epidemiologic divide conference, Washington DC, USA, May 4-6, 2009. Scientific programme and book of abstracts. Bethesda: National Cancer Institute; 2009:20.

Degteva MO, Anspaugh LR, Napier BA. JCCRER Project 1.1 - Further study of uncertainty, confounding, and validation of the doses in the Techa River Dosimetry System. In: Joint Coordinating Committee for Radiation Effects Research; $7^{\text {th }}$ international U.S. - Russian meeting; September 16-17, 2009; Washington D.C.; Participant Booklet. Washington DC: US Department of Energy; 2009:E1.

Fattibene P, De Coste V, Onori S, Veronese I, Giussani A, Cantone MC, Shishkina E. Beta dosimetry in teeth from 90Sr exposed subjects. In: Radiation protection: From knowledge to action, Proceedings of second European congress on radiation protection. Paris: Societe Francaise de Radioprotection; CD-ROM; Paper No. P-278; 2006.

Fattibene P, De Coste V, Guttler A, Shishkina E, Wieser A. Dosimetric properties of the incisor teeth. Part 1: Influence of sample mass on dose estimate. In: The $2^{\text {nd }}$ international conference on biodosimetry and $7^{\text {th }}$ international symposium on EPR dosimetry and applications; Scientific Program BiodosEPR-2006. Bethesda: Uniformed Services University of the Health Sciences (USUHS); Abstract No C-4; 2006.

Fattibene P, Veronese I, Ripamonti D, Cantone MC, De Coste V, Guissani A, Onori S, Shishkina E, Wieser A. Combined ER and TL measurements of Sr-90 contaminated teeth of Techa River residents. In: The $2^{\text {nd }}$ international conference on biodosimetry and $7^{\text {th }}$ international symposium on EPR dosimetry and applications; Scientific Program BiodosEPR-2006.

Bethesda: Uniformed Services University of the Health Sciences (USUHS); Abstract No P-30; 2006.

Fattibene P, Shishkina E, Wieser A, De Coste V, Degteva M, Ivanov D, Onori S. EPR measurements of baseline exposure of the Techa River population. In: Fifth international workshop on radiation risk research in Southern Urals; Scientific programme and book of abstracts. Neuherberg: GSF-National Research Center for Environment and Health; 2007:36.

Fattibene P, De Coste V, Güttler A, Ivanov DV, Shishkina E, Wieser A. EPR dose response of incisor teeth. Proceedings of 15th solid state dosimetry conference. Delft: Delft University of Technology; 2007: N 36602.

Glagolenko Yu, Mokrov Yu, Stukalov P, Aleksakhin A, Degteva M, Vorobiova M, Anspaugh L, Napier B. Source-term reconstruction for the Techa River situation on the basis of archival data. In: Fifth international workshop on radiation risk research in Southern Urals. Scientific programme and book of abstracts. Neuherberg: GSF-National Research Center for Environment and Health; 2007:32.

Göksu HY, Wieser A, Semiochkina N, El-Faramawy N, Degteva M, Jacob P. The use of thin layer $\alpha-\mathrm{A} 12 \mathrm{O} 3: \mathrm{C}$ dosemeters for the assessment of dose in teeth due to $\mathrm{Sr}-90$ incorporation and comparison with EPR dosimetry. In: The 13th international conference on solid state dosimetry, 9-13 July 2001, Athens, Greece, Program and abstracts. Tel Aviv:

International Solid State Dosimetry Organization; 2001:139.

Guttler A, Wieser A, Fattibene P, De Coste V, Shishkina EA. Dosimetric properties of the incisor teeth. Part 2: Comparison of EPR dose response of enamel from incisors and 
molars. In: $2^{\text {nd }}$ international conference on biodosimetry and $7^{\text {th }}$ international symposium on EPR dosimetry and applications, scientific program BiodosEPR-2006. Bethesda:

Uniformed Services University of the Health Sciences (USUHS); Abstract No P-5; 2006.

Harrison JD, Bolch WE, Degteva MO, Eckerman KF, Fell TP, Phipps AW, Shagina NB.

Developments in bone dosimetry and dose assessments for Techa River residents and Mayak workers. In: Fifth international workshop on radiation risk research in Southern Urals, Scientific programme and book of abstracts. Neuherberg: GSF-National Research Center for Environment and Health; 2007:40.

Ivanov DV, Bayankin SN, Degteva MO, Shishkina EA, Wieser A. Evaluation of uncertainty of the EPR dosimetry method. In: Book of abstracts for the IXth international symposium, 'Ural Atomic, Ural Industrial.' Ekaterinburg: Russian Academy of Sciences, Ural Branch; 2001:48-50 (in Russian and English).

Ivanov DV, Bayankin SN, Degteva MO, Shishkina EA. Using human teeth for retrospective EPR dosimetry for Urals population. In: Book of abstracts for the Xth international symposium, 'Ural Atomic, Ural Industrial.' Ekaterinburg: Institute of Industrial Ecology; 2002:68-69 (in Russian) 70 (in English).

Ivanov DV, Shishkina EA, Bayankin SN, Wieser A. EPR-measurements of the background doses for the Urals population. In: Widening the radiation protection world, Proceedings of $11^{\text {th }}$ international congress of the international radiation protection association. Madrid: International Radiation Protection Association; CD-ROM; ISBN:84-87078-05-2; Abstract No. 3f9; 2004.

Ivanov DV, Shishkina EA, Bayankin SN. Evaluation of the uncertainty and detection limits of EPR-dosimetry on tooth enamel at the Institute of Metal Physics. In: Proceedings of the $\mathrm{XI}^{\text {th }}$ international symposium, 'Ural Atomic, Ural Industrial.' Ekaterinburg: Institute of Industrial Ecology; 2005:47-50 (in Russian).

Ivanov DV. Radioecological investigation of exposure doses for the Urals population using EPR dosimetry technique. Ekaterinburg: Institute of Industrial Ecology; Doctoral thesis; 2005 (in Russian).

Ivanov D, Fattibene P, De Coste V, Wieser A, Baytimirov D, Shishkina EA. Features of using different equipment to prepare tooth enamel for EPR dosimetry. Radioprotection 43:150; 2008.

Kossenko MM, Vyushkova OV, Degteva MO, Nikolaenko LA, Epifanova SB. Risk of cancer among population exposed to radiation in the Techa Riverside communities. In: Chronic radiation exposure: Risk of late effects. Moscow: Izdat; 1996(2):21-33 (in Russian).

Kostyuchenko VA, Peremyslova LM, Popova IYa, Degteva MO, Zhidkova EM, Akleyev AV. Results of half a century monitoring of environmental effects of radiation accidents in the Urals. In: Chronic radiation exposure: Biological and Health Effects. Book of Abstracts. Chelyabinsk: Urals Research Center for Radiation Medicine; 2005:120 (in English) and 136-137 (in Russian).

Krestinina LYu, Preston DL, Vyushkova OV, Thomas T, Akleyev AV, Degteva MO, Startsev NV, Anspaugh LR, Napier BA, Ron E. Cancer mortality follow-up in the Extended Techa River Cohort. In: Workshop on radiation risk research in Southern Urals, book of abstracts. Neuherberg: GSF-National Research Center for Environment and Health; 2002. Krestinina LYu, Davis F, Ostroumova EV, Epifanova SB, Degteva MO, Preston DL, Akleyev AV. Solid cancer incidence in the Techa River Cohort. In: Medical and Ecological 
Effects of Ionizing Radiation (MEEIR-IV). Proceedings of IV international scientificpractical conference. Tomsk: Seversk Biophysics Research Center; 2007:38-39 (in Russian).

Krivoshchapov VA, Zalyapin VI. Reconstruction of the dynamics of the intake of strontium-90 for the population in the village of Muslyumovo. In: Book of abstracts for the IXth international symposium, 'Ural atomic, Ural industrial.' Ekaterinburg: Russian Academy of Sciences, Ural Branch; 2001:77-78 (in Russian).

Krivoschapov VA, Zalyapin VI. Application of numerical methods for the reconstruction of the dynamics of strontium-90 intake for residents of Muslyumovo village on the basis of measurements of strontium-90 in tooth enamel. In: Proceedings of the first regional conference on "Adaptation of biological systems to natural and extreme conditions." Chelyabinsk: State Pedagogical University; 2001:83-88 (in Russian).

Krivoshchapov VA. Restoration of dynamics of intake of strontium-90 by the inhabitants of the village of Metlino on the basis of measurements of beta-activity in tooth enamel. In:

Proceedings of second regional conference on "Adaptation of biological systems to natural and extreme conditions." Chelyabinsk: Chelyabinsk State Pedagogical University; 2002:3-10 (in Russian).

Krivoshchapov VA, Shishkina EA. Application of optical-stimulated luminescence as a method of digital beta-radiography for evaluation of strontium-90 distribution in calcified macrosamples. In: Proceedings of the first international scientific conference on "Adaptation of biological systems to natural and extreme conditions," Chelyabinsk, Russia, October 9-11, 2006. Chelyabinsk: State Pedagogical University; 2006:33-38 (in Russian).

Krivoshchapov VA, Tolstykh EI, Shagina NB, Degteva MO. Study of solution stability for biophysics inverse problem. In: Proceedings of the $2^{\text {nd }}$ international scientific conference on "Adaptation of biological systems to natural and extreme conditions," Chelyabinsk, Russia. Chelyabinsk: State Pedagogical University; Vol. 1:6-9; 2008 (in Russian).

Krivoshchapov VA, Shishkina EA. PSL method for evaluation of spatial distribution of $90 \mathrm{Sr}$ in biological samples. In: Late health effects of ionizing radiation: Bridging the experimental and epidemiologic divide conference, Washington DC, USA, May 4-6, 2009. Scientific programme and book of abstracts. Bethesda: National Cancer Institute; 2009: 67.

Krivoshchapov V, Shishkina E. An approach to evaluation of strontium-90 spatial distribution in calcified biological samples using PCL method of digital autoradiography. In: Proceedings of 54th Annual Meeting of the Health Physics Society, 12-16 July 2009, Minneapolis, Minnesota, USA. http://hps.org/meetings/meeting8.html.

Kursheva TS, Chuvakova D, Shishkina EA. Creation of voxel phantoms of human teeth: the first low incisor as an example. In: Proceedings of the $2^{\text {nd }}$ international scientific conference on "Adaptation of biological systems to natural and extreme conditions," Chelyabinsk, Russia. Chelyabinsk: State Pedagogical University; Vol. 1:9-15; 2008 (in Russian).

Lyubashevsky N, Starichenko V, Shishkina EA. The theory of individual variability of osteotropic radionuclides metabolism. In: Proceedings 1996 international congress on radiation protection. Seibersdorf: International Radiation Protection Association; ISBN 39500255-4-5; 1996, Vol. 3:128-130. 
Meckbach R, Taranenko V, Göksu HY, Bougrov NG, Degteva MO, Vorobiova MI, Jacob P. Verification of external gamma doses at the Techa River by luminescence measurements and Monte Carlo simulations of radiation transport. In: Workshop on radiation risk research in Southern Urals, book of abstracts. Neuherberg: GSF-National Research Center for Environment and Health; 2002.

Napier BA (Contact person). Radiation exposure study offers rare opportunity. In:

Environmental updates. Duxbury, MA: Battelle Memorial Institute; Battelle's newsletter on international and environmental projects; Spring 2001:2.

Napier BA. Major radionuclide releases to the environment from the Russian Mayak Production Association. Health Phys 82:S161-S162; 2002.

Napier BA, Degteva MO, Anspaugh LR, Vorobiova MI, Kozheurov VP, Tolstykh EI.

Environmental radiation dose reconstruction for U.S. and Russian weapons production facilities: Hanford and Mayak. In: Risk methodologies for technological legacies.

Boston: Kluwer; Chapter 9; 2003:149-182.

Orlenko SP, Tikunov DD, Ivannikov AI, Shishkina EA, Petin DV, Napalko MV, Borysheva NB, Shved VA, Skvortsov VG, Stepanenko VF. Instrumental assessment of internal dose for the samples of mineralized tooth tissues from the vicinity of the Techa River. In: Chronic radiation exposure: Biological and health effects, book of abstracts. Chelyabinsk: Urals Research Center for Radiation Medicine; 2005:93-94 (in English) and 107 (in Russian).

Peremyslova LM, Kostyuchenko VA, Degteva MO, Popova IYa, Safronova NG. Radiation ecological consequences of contamination of Chelyabinsk Oblast territory as a result of windblown radionuclides from Karachay Lake in 1967. In: Book of abstracts for the Xth international symposium, 'Ural atomic, Ural industrial.' Ekaterinburg: Institute of Industrial Ecology; 2002:145-146 (in Russian).

Peremyslova LM, Kostyuchenko VA, Popova IYa, Degteva MO, Tolstykh EI, Tsvetkova NG. Intakes of strontium-90 and cesium-137 with diet, internal dose from irradiation of the population of the territory of the Karachay trace for 1967-2001. In: Book of abstracts, Jubilee scientific conference on hygienic, dosimetric, and medical-biological aspects of long-term effects of chronic irradiation. Ozersk: Southern Urals Biophysics Institute; 2003:136-137 (in Russian).

Peremyslova LM, Akleyev AV, Kostyuchenko VA, Degteva MO, Tolstykh EI. Dietary intakes and internal exposure doses received by residents of the Karachay Trace. In: Widening the radiation protection world, Proceedings of $11^{\text {th }}$ international congress of the International Radiation Protection Association. Madrid: International Radiation Protection Association; CD-ROM; ISBN:84-87078-05-2; Paper No. 7c12; 2004.

Peremyslova LM, Kostyuchenko VA, Popova IYa. Comparative analysis of strontium-90 and cesium-137 migration in milk at the East-Urals Radioactive Trace and Karachay Trace. In: Proceedings of all-Russian scientific conference on "Adaptation of biological systems to natural and extreme conditions." Chelyabinsk: State Pedagogical University; 2004:215220 (in Russian).

Peremyslova LM, Kostyuchenko VA, Popova IYa, Shagina NB. Characteristics of the decrease of long-lived radionuclides content in food chain on the East-Urals Radioactive Trace and the Karachay Trace. In: Proceedings of the $\mathrm{XI}^{\text {th }}$ international symposium, 'Ural atomic, Ural industrial.’ Ekaterinburg: Institute of Industrial Ecology; 2005:297-300 (in Russian and English). 
Peremyslova LM, Kostyuchenko VA, Popova IYa, Melnikov VS. Contemporary levels of radioactive contamination by long-lived radionuclides of the Techa River in Chelyabinsk Oblast. In: Proceedings of the first international scientific conference on "Adaptation of biological systems to natural and extreme conditions," Chelyabinsk, Russia, October 9-11, 2006. Chelyabinsk: State Pedagogical University; 2006:38-40 (in Russian).

Peremyslova LM, Kostyuchenko VA, Popova IYa, Tolstykh EI. Results of long-term investigations of the radio-ecological conditions on the Iset River. In: Medical and ecological effects of ionizing radiation (MEEIR-IV). Proceedings of IV international scientific-practical conference. Tomsk: Seversk Biophysics Research Center; 2007:175176 (in Russian).

Peremyslova LM, Kostyuchenko VA, Popova IYa, Tolstykh EI. Long-term monitoring of radioecological conditions of the Iset river. In: Proceedings of the $2^{\text {nd }}$ International Conference "Adaptation of biological systems to natural and extreme conditions." Chelyabinsk: State Pedagogical University, Vol. 1:56-59; 2008 (in Russian).

Romanyukha AA, Degteva MO, Seregenkov VA, Kozheurov VP, Vorobiova MI, Vasilenko EA, Wieser A, Kleshchenko ED, Shishkina EA, Khokhryakov VF. Individual dose reconstruction for Ural residents based on electron spin resonance signal of teeth. In: Chronic radiation exposure: Risk of late effects. Chelyabinsk: Urals Research Center for Radiation Medicine; 1995:67-68 (in Russian) 138-139 (in English).

Romanyukha AA, Degteva MO, Kozheurov VP, Wieser A, Ignatiev EA, Jacob P, Vorobiova MI. Preliminary results of the study in the Urals region using EPR method on tooth enamel. In: Chronic radiation exposure: Risk of late effects. Moscow: Izdat; 1996(2):60-75 (in Russian).

Romanyukha AA, Koshta AA, Ignatiev EA, Degteva MO, Shishkina EA, Kozheurov VP, Vorobiova MI, Wieser A, Jacob P. Retrospective evaluation of the external component of individual exposure dose for the residents of the Techa riverside. In: Book of abstracts for the IVth international symposium, 'Ural atomic, Ural industrial.' Ekaterinburg: Russian Academy of Sciences, Ural Branch; 1996:147-150 (in Russian and English).

Romanyukha AA, Degteva MO, Kozheurov VP, Wieser A, Jacob P, Vorobiova M I, Ignatiev EA, Shishkina EA, Koshta AA. Retrospective evaluation of external component of individual doses for Techa Riverside. In: Proceedings 1996 international congress on radiation protection. Seibersdorf: International Radiation Protection Association; ISBN 39500255-4-5; 1996, Vol. 3:111-113.

Shagina NB, Degteva MO, Tolstykh EI. Uncertainty analysis of strontium retention in humans using the method of stochastic modeling. In: Proceedings of Moscow State Engineering Physics Institute Scientific Session “MEPI - 2000.” Moscow: Moscow State Engineering Physics Institute; 2000(5):22-23 (in Russian).

Shagina NB, Kozheurov VP, Degteva MO, Tolstykh EI, Tokareva EE. Study of radionuclide body-burden variability for the population of the Urals region. In: Proceedings of Snezhinsk Physics Technical Institute Scientific Session "Snezhinsk and Science." Snezhinsk: Russian Federal Nuclear Center - All-Russian Institute of Technical Physics; 2000(1):337-338 (in Russian).

Shagina NB, Degteva MO, Tolstykh EI. Uncertainty analysis of strontium retention in humans resulting from individual variability in metabolic parameters. In: Harmonization of radiation, human life and the ecosystem, Proceedings of 10th international congress on 
radiation protection. Hiroshima: International Radiation Protection Association; CDROM; Paper No. P-3a-128; 2000.

Shagina NB, Kozheurov VP, Degteva MO, Tolstykh EI, Tokareva EE. Study of 90Sr bodyburden variability for the population of the Urals Region. In: Proceedings of the fifth international symposium on environmental contamination in Central and Eastern Europe. Tallahassee: Institute for International Cooperative Environmental Research, Florida State University; DOE/EM-0584, Abstract ID726; 2000.

Shagina NB, Kozheurov VP, Degteva MO, Tolstykh EI, Tokareva EE. Study of 90Sr bodyburden variability for subpopulations in the Urals region. In: Book of abstracts for the IXth international symposium, 'Ural Atomic, Ural Industrial.' Ekaterinburg: Russian Academy of Sciences, Ural Branch; 2001:185-188 (in Russian and English).

Shagina, N.B.; Degteva, M.O.; Tolstykh, E.I. Validation of biokinetic models for strontium based on data on global fallout and data on Techa River. In: Proceedings of the First Regional Conference on "Adaptation of biological systems to natural and extreme conditions." Chelyabinsk: State Pedagogical University; 2001:56-62 (in Russian).

Shagina NB, Napier BA, Degteva MO, Tolstykh EI, Vorobiova MI, Anspaugh LR. Uncertainty analysis for doses estimated by use of the Techa River Dosimetry System. In: Workshop on radiation risk research in Southern Urals, book of abstracts. Neuherberg: GSF-National Research Center for Environment and Health; 2002.

Shagina NB, Degteva MO, Tolstykh EI. Age and gender dependent biokinetic model for strontium metabolism in humans. In: Book of abstracts for the $\mathrm{X}^{\text {th }}$ international symposium, 'Ural Atomic, Ural Industrial.' Ekaterinburg: Institute of Industrial Ecology; 2002:205-207 (in Russian) 207-208 (in English).

Shagina NB, Degteva MO, Tolstykh EI, Berkovski V. Update and improvements in the model for strontium metabolism. In: Scientific programme abstracts for the workshop on internal dosimetry of radionuclides. Occupational, public and medical exposure. Oxford: National Radiological Protection Board; Session 13; 2002.

Shagina NB, Tolstykh EI, Degteva MO, Kozheurov VP, Tokareva EE, Zalyapin VI. Estimation of the rate of elimination of strontium from the human body for long periods after exposure: analysis of data for the Techa River. In: Proceedings of second regional conference on "Adaptation of biological systems to natural and extreme conditions." Chelyabinsk: Chelyabinsk State Pedagogical University; 2002:56-65 (in Russian).

Shagina NB. Development of an age- and gender-dependent model for strontium for the Urals population. Ekaterinburg: Institute of Industrial Ecology; Doctoral thesis; 2003 (in Russian).

Shagina NB, Degteva MO, Tolstykh EI. Development of an age- and gender-specific model for strontium metabolism in humans. In: Widening the radiation protection world, Proceedings of 11th international congress of the international radiation protection association. Madrid: International Radiation Protection Association; CD-ROM; ISBN:8487078-05-2; Paper No. 3a45; 2004.

Shagina NB, Degteva MO, Tolstykh EI. The role of dosimetric and biokinetic models for strontium for internal dose assessment. In: Proceedings of all-Russian scientific conference on "Adaptation of biological systems to natural and extreme conditions," Chelyabinsk, Russia, October 11 -15, 2004. Chelyabinsk: State Pedagogical University 2004:251 - 258 (in Russian). 
Shagina NB. Analysis of bone dosimetric models to estimate internal doses from incorporated strontium-90. In: Proceedings of the $\mathrm{XI}^{\text {th }}$ international symposium, 'Ural atomic, Ural industrial,' Ekaterinburg, Russia, February 7-11, 2005. Ekaterinburg: Institute of Industrial Ecology; 2005:142-145 (in Russian and English).

Shagina NB, Bougrov NG, Degteva MO. An application of in vivo whole-body counting technique for studying strontium metabolism and internal dose reconstruction for the Techa River population. In: Proceedings of $19^{\text {th }}$ nuclear physics divisional conference of the European Physical Society, "New trends in nuclear physics applications and technology," Pavia, Italy, September 5-9, 2005. European Physical Society ECA Series, Vol. 29F:90; 2005.

Shagina NB, Degteva MO, Tolstykh EI, Zalyapin VI, Anspaugh LR, Napier BA. Reduction of the uncertainties in the internal doses from strontium-90 for the Extended Techa River Cohort. III international symposium, 'Chronic radiation exposure: Biological and health effects,' book of abstracts. Chelyabinsk: Urals Research Center for Radiation Medicine 2005:99 (in English) 113-114 (in Russian).

Shagina NB, Degteva MO, Tolstykh EI. Assessment of the internal dose from 90Sr incorporated in the human skeleton. In: III international symposium, 'Chronic radiation exposure: Biological and health effects,' book of abstracts. Chelyabinsk: Urals Research Center for Radiation Medicine 2005:99-100 (in English) 114 (in Russian).

Shagina N.B.; Tolstykh E.I.; Peremyslova L.M.; Degteva M.O.; Tokareva E.E. Strontium-90 in bone tissues of residents of Chelyabinsk Oblast. In: Book of abstracts of the $3^{\text {rd }}$ youth scientific conference, 'Urals nuclear industrial complex: Problems and perspectives.' Ozersk: Mayak Central Laboratory; 2005:76-77 (in Russian).

Shagina NB, Tolstykh EI, Vyushkova OV, Zalyapin VI, Degteva MO. Assessments of the cortical bone resorption rates for men and women aged 30-80 years in a longitudinal ( 25 years) study using $90 \mathrm{Sr}$ as a radioactive tracer. In: Proceedings of the $2^{\text {nd }}$ joint meeting of the European Calcified Tissue Society and the International Bone and Mineral Society. Bristol, UK and Washington, USA: ECTS-IBMS; CD-ROM; paper No. P028-Su; 2005. Shagina NB, Tolstykh EI, Fell TP, Harrison JD, Phipps AW, Degteva MO. In utero and postnatal haemopoietic tissue doses resulting from maternal ingestion of strontium isotopes from the Techa River. In: Internal dosimetry of radionuclides: Occupational, public and medical exposure, book of abstracts. Paris: IRSN/HPA; 2006:159.

Shagina NB, Tolstykh EI, Degteva MO. Assessment of cortical resorption rate as a required parameter for biokinetic model of bone-seeking radionuclides in humans. In: Proceedings of the first international scientific conference on "Adaptation of biological systems to natural and extreme conditions," Chelyabinsk, Russia, October 9-11, 2006. Chelyabinsk: State Pedagogical University; 2006:63-67 (in Russian).

Shagina NB, Tolstykh EI, Fell TP, Harrison JD, Phipps AW, Degteva MO. Assessment of the internal dose from strontium-90 ingested with breast milk for the offspring of Techa River residents. In: Fifth international workshop on radiation risk research in Southern Urals. Scientific programme and book of abstracts. Neuherberg: GSF-National Research Center for Environment and Health; 2007:39.

Shagina NB, Tolstykh EI, Degteva MO, Fell TP, Harrison JD. Improvement of strontium biokinetic model for assessment of in utero exposure doses. In: Proceedings of the $2^{\text {nd }}$ 
international conference "Adaptation of biological systems to natural and extreme conditions." Chelyabinsk: State Pedagogical University; Vol. 1:20-25; 2008 (in Russian).

Shagina NB, Tolstykh EI, Harrison JD, Fell TP, Bolch WE, Degteva MO. Improved assessments of doses to the Techa River Offspring Cohort from maternal intakes of strontium-90. In: Late health effects of ionizing radiation: Bridging the experimental and epidemiologic divide conference, Washington DC, USA, May 4-6, 2009. Scientific programme and book of abstracts. Bethesda: National Cancer Institute; 2009:54.

Shishkina EA. The tooth as a dosimetric system. In: Chronic radiation exposure: Risk of late effects. Chelyabinsk: Urals Research Center for Radiation Medicine; 1995:66 (in Russian) 136 (in English).

Shishkina EA. Experience of the reconstruction of individual doses absorbed by mammals under radioecological studies. Ekaterinburg: Institute of Plant and Animal Ecology; Doctoral thesis; 1998 (in Russian).

Shishkina EA, Shved VA. Assessment of internal exposure in tooth tissues due to incorporated 90Sr. In: Chronic radiation exposure: Possibilities of biological indication. Chelyabinsk: Urals Research Center for Radiation Medicine; 2000:192 (in Russian and English).

Shishkina EA, Shved VA. Reconstruction of internal cumulative dose for dental tissues. In: Problems of ecology and ecological education in the Chelyabinsk Region. Chelyabinsk: Chelyabinsk State Pedagogical University; 2001:96-100 (in Russian).

Shishkina EA, Degteva MO, Ivanov DI, Bayankin SN, Shved VA. Investigation of tooth enamel as personal dosimeter in retrospective EPR dosimetric studies. In: Book of abstracts for the Xth international symposium, 'Ural atomic, Ural industrial.' Ekaterinburg: Institute of Industrial Ecology; 2002:215-216 (in Russian).

Shishkina EA, Shved VA, Mitch M. Opportunities for use of photoluminescence for study of the distribution of strontium-90 in tooth fabric. In: Proceedings of second regional conference on "Adaptation of biological systems to natural and extreme conditions." Chelyabinsk: Chelyabinsk State Pedagogical University; 2002:81-87 (in Russian).

Shishkina EA, Göksu NY, El-Faramawy NA, Semiochkina N. Calibration and application of the TL beta counting method for determination of $90 \mathrm{Sr}$ concentration in the tooth tissues. In: Widening the radiation protection world, Proceedings of 11th international congress of the International Radiation Protection Association. Madrid: International Radiation Protection Association; CD-ROM; ISBN:84-87078-05-2; Abstract No. 3h66; 2004.

Shishkina EA, Degteva MO, Shved VA, Ivanov DV, Bayankin SN, Wieser A, Göksu Y, ElFaramawy N. Results of long-term study performed by EPR and accompanying methods of tooth dosimetry for riverside residents of Techa River region. In: III international symposium, 'Chronic radiation exposure: Biological and health effects,' book of abstracts. Chelyabinsk: Urals Research Center for Radiation Medicine 2005:100 (in English) 114115 (in Russian).

Shishkina EA, Fattibene P, Wieser A, Degteva MO, Onori S, Ivanov DV, Shved VA, Bayankin SN, Knyazev VA, Vasilenko EK, Gorelov M. EPR dosimetry of radiation background in the Urals region. In: Radiation protection: from knowledge to action, Proceedings of second European congress on radiation protection. Paris: Societe Francaise de Radioprotection; CD-ROM; Paper No. TA-33; 2006.

Shishkina EA. A new method of beta-radiography: Application of optical-stimulated luminescence for quantitative description of strontium-90 spatial distribution in bone 
samples. In: Proceedings of the first international scientific conference on "Adaptation of biological systems to natural and extreme conditions," Chelyabinsk, Russia, October 9-11, 2006. Chelyabinsk: State Pedagogical University; 2006:70-73 (in Russian).

Shishkina E, Göksu HY, Semiochkina N, Wieser A, Ivanov D, Shved V, Tolstykh E, Degteva M. Estimation of $90 \mathrm{Sr}$ contamination in the tooth tissues and expected levels of internal doses in the tooth enamel for Techa River residents. In: Fifth international workshop on radiation risk research in Southern Urals. Scientific programme and book of abstracts. Neuherberg: GSF-National Research Center for Environment and Health; 2007:37.

Shishkina EA, Lyubashevsky NM. To the issue on dosimetry of internal exposure of murine rodents by $90 \mathrm{Sr}$ and $90 \mathrm{Y}$ isotopes In: Proceedings of the $2^{\text {nd }}$ international conference "Adaptation of biological systems to natural and extreme conditions." Chelyabinsk: State Pedagogical University; Vol. 1:25-30; 2008 (in Russian).

Shishkina E, Ivanov D, Fattibene P, Wieser A, Degteva M. Numeric experiment for analysis of uncertainty of spectra processing in EPR dosimetry. Radioprotection 43:152; 2008.

Shishkina E, Ivanov D, Wieser A, Fattibene P, Volchkova A, Semioshkina N, El-Faramey N, Veroneze I, Degteva M.. Tooth dosimetry for residents of Techa Riverside territories. In: Late health effects of ionizing radiation: Bridging the experimental and epidemiologic divide conference, Washington DC, USA, May 4-6, 2009. Scientific programme and book of abstracts. Bethesda: National Cancer Institute; 2009:98.

Shved VA, Shishkina EA. Measurements of tooth sizes for the population of the Urals region. In: Proceedings of Snezhinsk Physics Technical Institute scientific session "Snezhinsk and Science." Snezhinsk: Russian Federal Nuclear Center - All-Russian Institute of Technical Physics; 2000(1):337-338 (in Russian).

Shved VA, Shishkina EA. Assessment of tooth tissues dose coefficients from incorporated strontium-90 for the Techa Riverside population. In: Proceedings of Moscow State Engineering Physics Institute Scientific Session "MEPI - 2000." Moscow: Moscow State Engineering Physics Institute; 2000(5):24-25 (in Russian).

Shved VA, Shishkina EA. Assessment of tooth tissue dose rate coefficients from incorporated strontium-90 in EPR dose reconstruction for the Techa riverside population. In: Harmonization of radiation, human life and the ecosystem, proceedings of 10th international congress on radiation protection. Hiroshima: International Radiation Protection Association; CD-ROM; Paper No. P-3a-212; 2000.

Shved VA, Shishkina EA. Sampling and odontometric measurements of teeth from donor residents in contaminated territory. In: Proceedings of the fifth international symposium on environmental contamination in Central and Eastern Europe. Tallahassee: Institute for International Cooperative Environmental Research, Florida State University; DOE/EM0584, Abstract ID732; 2000.

Shved VA, Shishkina EA, Bayankin SN, Wieser A. Energy dependence of tooth enamel sensitivity in EPR dosimetry. In: Book of abstracts for the IXth international symposium, 'Ural atomic, Ural industrial.' Ekaterinburg: Russian Academy of Sciences, Ural Branch; 2001:188-190 (in Russian and English).

Shved VA, Shishkina EA. Effect of a geometric tooth model on the results of dose assessment of the internal exposure of tooth tissues from incorporated strontium-90. In: Proceedings of the first regional conference on "Adaptation of biological systems to natural and extreme conditions.” Chelyabinsk: State Pedagogical University; 2001:63-68 (in Russian). 
Shved VA, Shishkina EA. Tooth tissues dose rate estimations from incorporated strontium-90. In: Book of abstracts for the Xth international symposium, 'Ural atomic, Ural industrial.' Ekaterinburg: Institute of Industrial Ecology; 2002:213 - 214 (in Russian) 215 (in English).

Shved VA, Tolstykh EI, Shishkina EA, Degteva MO, Ivanov DV. Age dependence of the contents of 90Sr in tooth fabric of the inhabitants of the shoreline regions of the Techa River. In: Proceedings of second regional conference on "Adaptation of biological systems to natural and extreme conditions." Chelyabinsk: Chelyabinsk State Pedagogical University; 2002:66-74 (in Russian).

Shved VA, Shishkina EA, Degteva MO, Ivanov DV, Bayankin SN, Göksu HY, Wieser A, Jacob P. Use of EPR spectrometry of tooth tissues for reconstruction of external dose from irradiation of residents of the Urals Region. In: Book of abstracts, Jubilee scientific conference on hygienic, dosimetric, and medical-biological aspects of long-term effects of chronic irradiation. Ozersk: Southern Urals Biophysics Institute; 2003:180-181 (in Russian).

Shved VA, Shishkina EA, Bayankin SN. Influence of hydroxyapatite structure on the energy dependence of enamel sensitivity. In: Widening the radiation protection world, Proceedings of 11th international congress of the International Radiation Protection Association. Madrid: International Radiation Protection Association; CD-ROM; ISBN:8487078-05-2; Abstract No. 3f16; 2004.

Shved VA, Shishkina EA, Ivanov DV, Bayankin SN, Veronese I. An investigation of the enamel absorbed dose due to radiation background. In: Proceedings of all-Russian scientific conference on "Adaptation of biological systems to natural and extreme conditions," Chelyabinsk, Russia, October 11 -15, 2004. Chelyabinsk: State Pedagogical University; 2004:263 - 269 (in Russian).

Shved VA, Degteva MO, Shishkina EA. Tooth tissues bank for residents of the Urals region and its application for dose reconstruction. In: Proceedings of the XIth international symposium, 'Ural atomic, Ural industrial,' Ekaterinburg, Russia, February 7-11, 2005. Ekaterinburg: Institute of Industrial Ecology; 2005:239-241 (in Russian).

Startsev NV, Akleyev AV, Degteva MO, Kossenko MM, Vyushkova OV, Kozheurov VP, Kozyrev AV, Khristevich NP. URCRM medico-dosimetric database "MAN." In: Proceedings of conference devoted to the 50th anniversary of the Federal Department of medico-biological and extreme problems under the Russian Ministry of Health. Moscow: Federal Department of the Ministry of Health of the Russian Federation; 1998:103 (in Russian).

Taranenko VA, Degteva MO, Meckbach, R. Gamma-field distribution near reservoir contaminated by radionuclides. In: Problems of ecology and ecological education in Chelyabinsk Region. Chelyabinsk: Chelyabinsk State Pedagogical University; 2001:8083 (in Russian).

Taranenko VA. Potential approach to the task of reconstructing accumulated dose in bricks of a mill building in the village of Metlino. In: Proceedings of second regional conference on "Adaptation of biological systems to natural and extreme conditions." Chelyabinsk: Chelyabinsk State Pedagogical University; 2002:49-56 (in Russian).

Taranenko VA. An application of Monte Carlo method for the evaluation of external exposure dose under radioactive contamination of river system. Ekaterinburg: Institute of Industrial Ecology; Doctoral thesis; 2006 (in Russian). 
Timofeev YS, Shishkina EA, Ivanov DV, Fattibene P, Wieser A, Degteva M. Application of experimental and numerical methods for estimation of uncertainties in EPR tooth dosimetry. In: Late health effects of ionizing radiation: Bridging the experimental and epidemiologic divide conference, Washington DC, USA, May 4-6, 2009. Scientific programme and book of abstracts. Bethesda: National Cancer Institute; 2009:100.

Timofeev YS, Shishkina EA, Zalyapin VI. Problem of uncertainty estimation in EPR-dosimetry. Proceedings of The $16^{\text {th }}$ International Conference "Mathematics. Computing. Education" January 19 - 24, 2009, Pushchino, Russia (in Russian). [Need publisher.]

Tokareva EE, Kozheurov VP, Tolstykh EI, Degteva MO. Analysis of in vivo measurements of 90Sr in human teeth and body. In: Proceedings of the fifth international symposium on environmental contamination in Central and Eastern Europe. Tallahassee: Institute for International Cooperative Environmental Research, Florida State University; DOE/EM0584, Abstract ID740; 2000.

Tokareva EE, Degteva MO, Tolstykh EI, Kozheurov VP. Analysis of factors affecting the levels of 90Sr-body-burdens for the Techa Riverside residents. In: Problems of ecology and ecological education in Chelyabinsk Region. Chelyabinsk: Chelyabinsk State Pedagogical University; 2001:84-88 (in Russian).

Tokareva EE, Tolstykh EI, Peremyslova LM, Shagina NB. The registry of strontium-90 content measurements in samples of bone tissue of the residents of the Urals region: Analysis of data for Chelyabinsk and Sverdlovsk Oblasts. In: Book of abstracts for the Xth international symposium, 'Ural atomic, Ural industrial.' Ekaterinburg: Institute of Industrial Ecology; 2002:195-197 (in Russian) 197-198 (in English).

Tolstykh EI, Degteva MO, Vorobiova MI, Kozheurov VP, Peremyslova LM. Reconstruction of 90Sr intake for population of the territory of East Urals Radiation Trace. In: Chronic radiation exposure: Possibilities of biological indication. Chelyabinsk: Urals Research Center for Radiation Medicine; 2000:192-193 (in Russian and English).

Tolstykh EI, Degteva MO, Kozheurov VP, Repin VS, Novak NYu, Berkovski V, Noßke D. Validation of biokinetic models for strontium: Analysis of the Techa River and Chernobyl data. In: Harmonization of radiation, human life and the ecosystem, Proceedings of 10th international congress on radiation protection. Hiroshima: International Radiation Protection Association; CD-ROM; Paper No. P-3a-129; 2000.

Tolstykh EI, Degteva MO, Kozheurov VP, Repin VS, Novak NYu, Berkovski V, Noßke D. Validation of biokinetic models for strontium: Analysis of the Techa River data. In: Book of abstracts for the VIIIth international symposium, 'Ural atomic, Ural industrial.'

Ekaterinburg: Russian Academy of Sciences, Ural Branch; 2000:288-291 (in Russian and English).

Tolstykh EI, Degteva MO, Kozheurov VP, Burmistrov DS. Strontium transfer from maternal skeleton to fetus evaluated on the basis of the Techa River data. In: Problems of ecology and ecological education in Chelyabinsk Region. Chelyabinsk: Chelyabinsk State Pedagogical University; 2001:88-91 (in Russian).

Tolstykh EI, Degteva MO, Peremyslova LM. Reconstruction of strontium-90 intake for residents of the East Urals Radioactive Trace area. In: Proceedings of the first regional conference on "Adaptation of biological systems to natural and extreme conditions." Chelyabinsk: State Pedagogical University; 2001:69-74 (in Russian). 
Tolstykh EI, Zalyapin VI, Krivoshchapov VA, Degteva MO, Kozheurov VP, Peremyslova LM, Anspaugh LR, Napier BA. Verification of 90Sr-intake levels for the Techa River residents. In: Workshop on radiation risk research in Southern Urals, book of abstracts. Neuherberg: GSF-National Research Center for Environment and Health; 2002.

Tolstykh EI, Degteva MO, Peremyslova LM, Zalyapin VI, Krivoshchapov VA, Vorobiova MI. Methodological approaches to reconstruct intakes of radionuclides by inhabitants of shoreline villages on the River Techa. In: Book of abstracts, Jubilee scientific conference on hygienic, dosimetric, and medical-biological aspects of long-term effects of chronic irradiation. Ozersk: Southern Urals Biophysics Institute; 2003:170-171 (in Russian).

Tolstykh EI, Tokareva EE, Peremyslova LM, Degteva MO. Bone mineral contents in samples of Urals residents as a function of age and gender. In: Proceedings of the XIX Pavlov Physiological Society Congress on "From genomics to integrative physiology," Ekaterinburg, Russia, September 19-24, 2004. Ekaterinburg: Urals Branch of Russian Academy of Sciences; 2004:215-216 (in Russian).

Tolstykh EI, Peremyslova LM, Shagina NB, Degteva MO, Tokareva EE. The characteristics of accumulation and elimination of long-lived radionuclides in residents of the Urals region. In: Proceedings of all-Russian scientific conference on "Adaptation of biological systems to natural and extreme conditions." Chelyabinsk: State Pedagogical University; 2004:242-248 (in Russian).

Tolstykh EI. The impact of ionizing radiation on the mineralization of human bone tissues: Retrospective analysis of data from the Urals region. In: Proceedings of international scientific conference on "Medical and ecological effects of ionizing radiation." Tomsk: Seversk Biophysical Scientific Center; 2005:204-206 (in Russian).

Tolstykh EI, Degteva MO, Zalyapin VI, Krivoshchapov VA, Peremyslova LM, Anspaugh LR, Napier BA. Reconstruction of long-lived radionuclide intakes for Techa Riverside residents. In: III international symposium, 'Chronic radiation exposure: Biological and health effects,' book of abstracts. Chelyabinsk: Urals Research Center for Radiation Medicine 2005:95 - 96 (in English) 109 (in Russian).

Tolstykh EI, Tokareva EE, Peremyslova LM, Shagina NB, Degteva MO. The retrospective analysis of mineral content in bone samples from donors aged 0-99 years living in the Southern Urals over the second half of the XX century. In: Proceedings of the $2^{\text {nd }}$ joint meeting of the European Calcified Tissue Society and the International Bone and Mineral Society. Bristol, UK and Washington, USA: ECTS-IBMS; CD-ROM; paper No. P027$\mathrm{Tu} ; 2005$.

Tolstykh EI. Age and gender dependences of skeletal mineralization for the residents of contaminated areas of the Urals region. Chelyabinsk: State Pedagogical University; Doctoral thesis; 2006 (in Russian).

Tolstykh EI, Degteva MO, Shishkina EA, Zalyapin VI. Possibilities of using human teeth for retrospective dosimetry: Analysis of the Techa River data. In: Internal dosimetry of radionuclides: Occupational, public and medical exposure; book of abstracts. Paris: IRSN/HPA; 2006:164.

Tolstykh EI, Shagina NB, Peremyslova LM, Degteva MO, Anspaugh LR, Napier BA. Reconstruction of dietary intake of short-lived radionuclides on the territory of East Urals Radioactive Trace: New approaches. In: Proceedings of the first international scientific conference on "Adaptation of biological systems to natural and extreme conditions", 
Chelyabinsk, Russia, October 9-11, 2006. Chelyabinsk: State Pedagogical University 2006: 54-58 (in Russian).

Tolstykh EI, Degteva MO, Shagina NB, Peremyslova LM. Retrospective assessment of radionuclides dietary intake: Experience from studies at the East Urals Radioactive Trace. In: Proceedings of scientific conference "Actual questions of radiation protection of general public,” St. Petersburg, Russia, December 4-7, 2006. St. Petersburg: Research Institute for Radiation Medicine; 2006:178-180 (in Russian).

Tolstykh EI, Shagina NB, Degteva MO. Bone tissue response to ionizing radiation:

Determination of the dose threshold using the results of investigations on the Techa River.

In: Medical and ecological effects of ionizing radiation (MEEIR-IV), Proceedings of IV international scientific-practical conference. Tomsk: Seversk Biophysics Research Center; 2007:133-135 (in Russian).

Tolstykh EI, Shagina NB, Degteva MO. Reconstruction of radionuclide intake with foodstuff in the EURT area: History of the problem and present-day approaches. In: Experience of overcoming of consequences of man-caused accidents and development of atomic technologies. Proceedings of scientific-practical conference devoted to fifty years from the accident in the Mayak PA. Chelyabinsk: Chelyabinsk Ministry for Radiation and Ecological Safety; 2007:263-264 (in Russian).

Tolstykh EI, Shagina NB, Tokareva EE, Peremyslova LM, Degteva MO. Computer registry of autopsy samples of human bone tissue as a basis for dosimetric, radio-ecological and anthropological research. In: Problems of ecology and border disciplines. Issue 11. Ekaterinburg: Urals State University; 2007:290-319 (in Russian).

Tolstykh EI, Shagina NB, Peremyslova LM, Degteva MO. Secular trend in decrease of mineral density of human bone tissue: influence of strontium-90. In: Proceedings of the $2^{\text {nd }}$ international conference "Adaptation of biological systems to natural and extreme conditions.” Chelyabinsk: State Pedagogical University; Vol. 1:104-109; 2008 (in Russian).

Trapeznikov AV, Molchanova IV, Karavaeva EN, Peremyslova LM, Mikhailovskaya LN, Popova IYa, Nikolkin VN, Vorobiova MI, Trapeznikova VN, Kostyuchenko BA, Korzhavin AV. The results of long-term investigations of some man-made radionuclides distribution in the main components of the Techa River. In: Problems of radioecology and frontier disciplines, V. 10. Nizhnevartovsk: "Alster"; 2007:46-66 (in Russian).

Ulanovsky A, Woda C, Bougrov N. Status of work on external dose reconstruction in the Techa River floodplains using TLD measurements and Monte Carlo modeling. In: Fifth international workshop on radiation risk research in Southern Urals. Scientific programme and book of abstracts. Neuherberg: GSF-National Research Center for Environment and Health; 2007:38.

Ulanovsky A, Woda C, Jacob P, Bougrov N. Advanced validation of population external exposures in radioactively contaminated Techa River Valley. In: Late health effects of ionizing radiation: Bridging the experimental and epidemiologic divide conference, Washington DC, USA, May 4-6, 2009. Scientific programme and book of abstracts. Bethesda: National Cancer Institute; 2009:101.

Veronese I, Fattibene P, Cantone MC, De Coste V, El-Faramawy N, Giussani A, Göksu Y, Martini M, Onori S, Ripamonti D, Shishkina EA, Wieser A. A methodological approach to dose assessment in human teeth with $\mathrm{EPR}$ and $\alpha-\mathrm{AL}_{2} \mathrm{O}_{3}: \mathrm{C}$ dosimetry. In: Widening the 
radiation protection world, Proceedings of 11th international congress of the International Radiation Protection Association. Madrid: International Radiation Protection Association; CD-ROM; ISBN:84-87078-05-2; Paper No. 3f2; 2004.

Veronese I, Fattibene P, Cantone MC, De Coste V, Giussani A, Onori S, Shishkina E. Correlation of EPR and TL measurements in various tooth components contaminated by Sr-90. In: Proceedings of 15th solid state dosimetry conference. Delft: Delft University of Technology; 2007: N 36626.

Volchkova AYu, Chuvakova DA, Shishkina EA. Development and application of an agedependent voxel phantom of the first human incisors for assessment of the internal dose from 90Sr. In: Late health effects of ionizing radiation: Bridging the experimental and epidemiologic divide conference, Washington DC, USA, May 4-6, 2009. Scientific programme and book of abstracts. Bethesda: National Cancer Institute; 2009:102.

Vorobiova MI. External dose reconstruction for the population exposed as a result of radioactive releases into the Techa River by the Mayak PA. Ekaterinburg: Institute of Industrial Ecology; Doctoral thesis; 2000 (in Russian).

Vorobiova MI, Degteva MO. Modeling of radionuclide transport in river for retrospective dosimetry purposes. In: Book of abstracts for the VIII' ${ }^{\text {th }}$ international symposium, 'Ural atomic, Ural industrial.' Ekaterinburg: Russian Academy of Sciences, Ural Branch; 2000:42-45 (in Russian and English).

Vorobiova MI, Degteva MO, Anspaugh LR, Napier BA. Reassessment of external doses for the Techa River residents. In: Chronic radiation exposure: Possibilities of biological indication. Chelyabinsk: Urals Research Center for Radiation Medicine; 2000:181-182 (in Russian and English).

Vorobiova MI, Degteva MO, Kostyuchenko VA. Characterization of radiation conditions in the Techa floodplain. In: Medical-biological and ecological impacts of radioactive contamination of the Techa River. Moscow: Federal Department of the Ministry of Health of the Russian Federation; 2000:24-47 (in Russian).

Vorobiova MI. External dose reconstruction for residents of the Techa River settlements. In: Proceedings of the first regional conference on "Adaptation of biological systems to natural and extreme conditions." Chelyabinsk: State Pedagogical University; 2001:51-56 (in Russian).

Vorobiova MI, Shishkina EA, Degteva MO, Shved VA, Tolstykh EI, Anspaugh LR, Napier BA, Ivanov DV, Bayankin SN, Wieser A, Jacob P, Nagy V, Desrosiers MR. Estimates and validation of external doses for individual members of the Extended Techa River Cohort and the Techa River Offspring Cohort. In: Workshop on radiation risk research in Southern Urals, book of abstracts. Neuherberg: GSF-National Research Center for Environment and Health; 2002.

Vorobiova MI, Degteva MO, Bougrov NG, Anspaugh L, Napier B. Problems of external dosimetry for residents of inhabited areas on the Techa River. In: Book of abstracts, Jubilee scientific conference on hygienic, dosimetric, and medical-biological aspects of long-term effects of chronic irradiation. Ozersk: Southern Urals Biophysics Institute; 2003:85 (in Russian).

Vorobiova MI, Degteva MO. On uncertainty of the source-term for the Techa River contaminated with liquid radioactive wastes from PA "Mayak." In: Proceedings of allRussian scientific conference on "Adaptation of biological systems to natural and extreme 
conditions," Chelyabinsk, Russia, October 11 -15, 2004. Chelyabinsk: State Pedagogical University; 2004:176 - 181 (in Russian).

Vorobiova MI, Glagolenko YuV, Trapeznikov AV, Cherepanova EI. Source-term reconstruction for the Techa River: Problems and resolution pathways. In: Proceedings of the XIth international symposium, 'Ural atomic, Ural industrial.' Ekaterinburg: Institute of Industrial Ecology; 2005:19-22 (in Russian and English).

Wieser A, Romanyukha AA, Bunzl K, Kracke W, Degteva MO, Kozheurov VP. The absorbed dose in tooth enamel by 90Sr body burden. In: Proceedings 1996 international congress on radiation protection. Seibersdorf: International Radiation Protection Association; ISBN 3-9500255-4-5; 1996, Vol. 1:425-435.

Wieser A, Fattibene P, Shishkina EA, Bayankin SN, De Coste V, Guttler A, Ivanov DV, Onori S. Inter-laboratory comparison of EPR dosimetry with tooth enamel in the SOUL project. In: The $2^{\text {nd }}$ international conference on biodosimetry and $7^{\text {th }}$ international symposium on EPR dosimetry and applications. Scientific program BiodosEPR-2006. Bethesda: Uniformed Services University of the Health Sciences (USUHS); Abstract No F-1; 2006.

Wieser A, Fattibene P, Shishkina EA, Bayankin SN, De Coste V, Güttler A, Ivanov DV, Onori

S. In: Proceedings of assessment of performance parameters for EPR dosimetry with tooth enamel. In: Proceedings of 15th solid state dosimetry conference. Delft: Delft University of Technology; 2007: N 36427.

Woda C, Ulanovsky A, Bougrov N, Jacob P. Progress in luminescence dosimetry in contaminated settlements. In: Late health effects of ionizing radiation: Bridging the experimental and epidemiologic divide conference, Washington DC, USA, May 4-6, 2009. Scientific programme and book of abstracts. Bethesda: National Cancer Institute; 2009:102.

Zalyapin VI, Krivoshchapov VA. Integral model of the dynamics of 90Sr intake. In: Proceedings of the 4th international conference on mathematical modeling of physical, economical, technical and social systems and processes. Ulyanovsk: Ulyanovsk State University; 2001:41-43 (in Russian).

Zalyapin VI, Krivoshchapov VA. Integral model of strontium intake dynamics. In: Abstracts of $9^{\text {th }}$ conference "Mathematics, computer, education", Dubna: Russian State Research Center; 2002:233 (in Russian).

Zalyapin VI, Krivoshchapov VA. Reconstruction of strontium-90 intake on the basis of in vivo measurements. In: Proceedings of $10^{\text {th }}$ conference "Mathematics, computer, education". Pushchino: Center for biological research; 2003:203 (in Russian).

Zalyapin VI, Krivoshchapov VA. Inverse problem of biophysics. Reconstruction of strontium90 intake with the use of in vivo measurements. In: All-Russian conference "Algorithmic analysis of unstable problem." Yekaterinburg: Ural State University; 2004:341-342 (in Russian).

\section{FINAL REPORT FOR THE FIRST PHASE OF PROJECT 1.1}

Degteva MO, Anspaugh LR, Napier B, Vorobiova MI, Tolstykh EI, Kozheurov VP, Kozyrev AV, Bougrov NG, Kovtun AN, Shagina NB, Shishkina EA, Tokareva EE, Taranenko VA. Development of an improved dose reconstruction system for the general population 
affected by the operation of the Mayak Production Association. Final Report on Project 1.1. Chelyabinsk and Salt Lake City: Urals Research Center for Radiation Medicine and University of Utah; March 2000 (in Russian and English).

\section{MILESTONE REPORTS FOR THE FIRST PHASE OF PROJECT 1.1}

(Enumeration corresponds to that specified in the proposal)

\section{Milestone 1}

Vorobiova MI, Degteva MO, Burmistrov DS, Safronova NG, Kozheurov VP, Anspaugh LR, Napier BA. Analytical review of historical monitoring data and modeled concentrations of radionuclides in Techa River water and sediments at specific locations over time. Description of hydrological data and models employed. Chelyabinsk and Salt Lake City: Urals Research Center for Radiation Medicine and University of Utah; Final report for Milestone 1; December 1997 (in Russian and English).

\section{Milestone 2}

Kozheurov VP, Kovtun AN, Degteva MO, Anspaugh LR, Napier BA. Calibration of wholebody counter SICH-9.1 for strontium-90, cesium-137 and potassium-40 using special phantoms. Chelyabinsk and Salt Lake City: Urals Research Center for Radiation Medicine and University of Utah; Final report for Milestone 2; October 1998 (in Russian and English).

\section{Milestone 3}

Tolstykh EI, Kozheurov VP, Burmistrov DS, Degteva MO, Vorobiova MI, Anspaugh LR, Napier BA. Individual-body-burden histories and resulting internal organ doses evaluated on the basis of the Techa River Dosimetry System approach. Chelyabinsk and Salt Lake City: Urals Research Center for Radiation Medicine and University of Utah; Final report for Milestone 3; October 1998 (in Russian and English).

\section{Milestone 4}

Bougrov NG, Burmistrov DS, Degteva MO, Vorobiova MI, Haskell E, Göksu HY, Jacob P, Anspaugh LR, Napier BA. Environmental thermoluminescent dosimetry measurements and their comparison with values calculated on the basis of historical monitoring data. Chelyabinsk and Salt Lake City: Urals Research Center for Radiation Medicine and University of Utah; Final report for Milestone 4; January 1999 (in Russian and English).

\section{Milestone 5}

Degteva MO, Vyushkova OV, Romanyukha AA. Feasibility analysis of the development of a special system for obtaining tooth samples from the Techa River residents. Chelyabinsk 
and Ekaterinburg: Urals Research Center for Radiation Medicine and Institute of Metal Physics; Final report for Milestone 5; July 1997 (in Russian and English).

\section{Milestone 6}

Vorobiova MI, Degteva MO, Kozyrev AV, Anspaugh LR, Napier BA. External doses evaluated on the basis of the Techa River Dosimetry System approach. Chelyabinsk and Salt Lake City: Urals Research Center for Radiation Medicine and University of Utah; Final report for Milestone 6; May 1999 (in Russian and English).

\section{Milestone 8}

Degteva MO, Anspaugh LR, Napier BA, Tolstykh EI, Shagina NB, Kozheurov VP, Vorobiova MI, Tokareva EE, Shishkina EA. Analysis of the main factors contributing to uncertainty in internal dose from ${ }^{90} \mathrm{Sr}$ and feasibility evaluation for reduction in uncertainty. Chelyabinsk and Salt Lake City: Urals Research Center for Radiation Medicine and University of Utah; Final report for Milestone 8; November 1999 (in Russian and English).

\section{Milestone 11}

Napier BA, Shagina NB, Degteva MO, Tolstykh EI, Vorobiova MI., Anspaugh LR. Preliminary uncertainty analysis for the doses estimated using the Techa River Dosimetry System 2000. Chelyabinsk and Salt Lake City: Urals Research Center for Radiation Medicine and University of Utah; Final report for Milestone 11; March 2000 (in Russian and English).

\section{OTHER PROJECT REPORTS FOR THE FIRST PHASE OF PROJECT 1.1}

\section{Final Report on Feasibility Study}

Degteva MO, Drozhko E, Anspaugh LR, Napier BA, Bouville A, Miller C. Dose reconstruction for the Urals population. Joint Coordinating Committee on Radiation Effects Research. Project 1.1-Final report. Livermore: Lawrence Livermore National Laboratory; UCRLID-123713; February 1996.

\section{Final Report on EPR Dosimetry (replacement of cancelled Milestone 9 Report)}

Haskell EH. Retrospective dosimetry using electron paramagnetic resonance (EPR) and thermoluminescence (TL) techniques in contaminated areas of the former Soviet Union. Final report of work performed at the Center of Applied Dosimetry. Salt Lake City: University of Utah; September 1998. 


\section{MILESTONE REPORTS FOR THE SECOND PHASE OF PROJECT 1.1}

(Enumeration corresponds to that specified in the proposal)

\section{Milestone 1}

Kozheurov VP, Zalyapin VI, Shagina NB, Tokareva EE, Degteva MO, Tolstykh EI, Anspaugh LR, Napier BA. Statistical analysis of individual dosimetric data and the evaluation of uncertainties in instrumental techniques used for 90Sr-body burden evaluation (whole body count and tooth-beta count). Chelyabinsk and Salt Lake City: Urals Research Center for Radiation Medicine and University of Utah; Final report for Milestone 1; September 2000 (in Russian and English).

\section{Milestone 2}

Shishkina EA, Shved VA, Degteva MO, Tolstykh EI, Ivanov DV, Bayankin SN, Anspaugh LR, Napier BA, Wieser A, Jacob P. Description of the computer database "tooth" and discussion of requirements for EPR measurements to support a validation study of external doses calculated by use of the Techa River Dosimetry System-2000.

Chelyabinsk and Salt Lake City: Urals Research Center for Radiation Medicine and University of Utah; Final report for Milestone 2; April 2001 (in Russian and English).

\section{Unscheduled Report}

Anspaugh LR, Degteva MO, Shishkina EA, Tolstykh EI, Napier BA. Commentary on the number of teeth required for analysis by EPR in order to validate estimates of external dose for members of the extended Techa River Cohort. Chelyabinsk and Salt Lake City: Urals Research Center for Radiation Medicine and University of Utah; Unscheduled report; September 2001.

\section{Milestone 3, Part 1}

Tolstykh EI, Zalyapin VI, Krivoshchapov VA, Shagina NB, Peremyslova LM, Degteva MO, Kozheurov VP, Safronova NG, Anspaugh LR, Napier BA. Verification of referentintake levels for strontium-90. Chelyabinsk and Salt Lake City: Urals Research Center for Radiation Medicine and University of Utah; Final report for Milestone 3, Part 1; September 2001 (in Russian and English).

\section{Progress Report for Milestone 4}

Shagina NB, Tolstykh EI, Zalyapin VI, Degteva MO, Kozheurov VP, Tokareva EE, Anspaugh LR, Napier BA. Statistical analysis of repeated measurements of strontium-90 body burdens and evaluation of age- and sex-dependencies of strontium-elimination rate during a period 25-45 years after intake. Chelyabinsk and Salt Lake City: Urals Research Center for Radiation Medicine and University of Utah; Progress Report for Milestone 4; January 2002. 


\section{Milestone 3, Part 2}

Shagina NB, Tolstykh EI, Degteva MO, Kozheurov VP, Anspaugh LR, Napier BA. Update and improvements in a model for the biokinetics of strontium. Chelyabinsk and Salt Lake City: Urals Research Center for Radiation Medicine and University of Utah; Final report for Milestone 3, Part 2; April 2002 (in Russian and English).

\section{Unscheduled Report}

Shishkina EA, Shved VA, Tolstykh EI, Degteva MO, Anspaugh LR. Investigation of the tooth as a complex dosimeter: Formation of dose in tooth enamel. Chelyabinsk and Salt Lake City: Urals Research Center for Radiation Medicine and University of Utah; Unscheduled Report; June 2002.

\section{Milestone 4}

Tolstykh EI, Zalyapin VI, Shagina NB, Krivoshchapov VA, Degteva MO, Tokareva EE, Anspaugh LR, Napier BA. Estimation of individual-to-model ratios (IMR) and their uncertainty for the Techa River residents. Chelyabinsk and Salt Lake City: Urals Research Center for Radiation Medicine and University of Utah; Final Report for Milestone 4; November 2002 (in Russian and English).

\section{Milestone 5}

Vorobiova MI, Degteva MO, Tolstykh EI, Safronova NG, Peremyslova LM, Anspaugh LR, Napier BA. Verification and evaluation of uncertainties for intake levels for non-strontium radionuclides with use of an improved Techa River Model. Chelyabinsk and Salt Lake City: Urals Research Center for Radiation Medicine and University of Utah; Final Report for Milestone 5; March 2003 (in Russian and English).

\section{Milestone 6}

Tokareva EE, Degteva MO, Mikusheva RK, Schennikova VN, Shagina NB, Shved VA, Anspaugh LR, Napier BA. Description of the household registry for the Techa River settlements. Chelyabinsk and Salt Lake City: Urals Research Center for Radiation Medicine and University of Utah; Final Report for Milestone 6; April 2003 (in Russian and English).

\section{Milestone 7, Part 1}

Shishkina EA, Shved VA, Degteva MO, Tolstykh EI, Ivanov DV, Bayankin SN, Wieser A, Göksu HY, El-Faramawy NA, Semiochkina N, Jacob P, Anspaugh LR, Napier, B.A. Issues in the validation of external dose: Background and internal dose components of 
cumulative dose estimated using the EPR method. Chelyabinsk and Salt Lake City: Urals

Research Center for Radiation Medicine and University of Utah; Final report for Milestone 7, Part 1; September 2003 (in Russian and English).

\section{Milestone 8}

Tolstykh EI, Zalyapin VI, Shagina NB, Krivoshchapov VA, Degteva MO, Tokareva EE, Anspaugh LR, Napier BA. Evaluation of ETRC subcohorts with different algorithms for 90Sr body burden estimation and assessment of their uncertainties. Chelyabinsk and Salt Lake City: Urals Research Center for Radiation Medicine and University of Utah; Final report for Milestone 8; September 2003 (in Russian and English).

\section{Milestone 16}

Vorobiova MI, Degteva MO, Safronova NG, Kozyreva OV, Ivanov VM, Dimov GP, Romanskaya YuYu, Golikov VYu, Barkovsky AN, Anspaugh LR, Napier BA. Description of the X-ray diagnostic procedures registry for the Techa River residents. Chelyabinsk and Salt Lake City: Urals Research Center for Radiation Medicine and University of Utah; Final report for Milestone 16; November 2003 (in Russian and English).

\section{Milestone 10}

Peremyslova LM, Tolstykh EI, Vorobiova MI, Degteva MO, Safronova NG, Shagina NB, Anspaugh LR, Napier BA. Analytical review of data available for the reconstruction of doses due to residence on the East Ural Radioactive Trace and the territory of windblown contamination from Lake Karachay. Chelyabinsk and Salt Lake City: Urals Research Center for Radiation Medicine and University of Utah; Final report for Milestone 10; September 2004 (in Russian and English).

\section{Milestone 7, Part 2}

Degteva MO, Vorobiova MI, Shved VA, Shishkina EA, Ivanov DV, Bayankin SN, Tolstykh EI, Zalyapin VI, Wieser A, Jacob P, Anspaugh LR, Napier, B.A. Validation of TRDS external dose estimates by EPR measurements supported by assessments of Strontium-90 concentration and Monte Carlo simulations of electron transport in dental tissues. Chelyabinsk and Salt Lake City: Urals Research Center for Radiation Medicine and University of Utah; Final report for Milestone 7, Part 2; September 2004 (in Russian and English).

\section{Milestone 9}

Degteva MO, Vorobiova MI, Akhramenko BN, Shagina NB, Safronova NG, Anspaugh LR, Napier BA. Report on the uncertainties in TRDS external dose estimates evaluated on the basis of modeling data and the distributions of external exposure components of EPR measurements. Chelyabinsk and Salt Lake City: Urals Research Center for Radiation 
Medicine and University of Utah; Final report for Milestone 9; April 2005 (in Russian and English).

\section{Unscheduled Report}

Degteva MO, Vorobiova MI, Shagina NB, Anspaugh LR, Napier BA. A review of data on releases of radioactive wastes from the "Mayak" Production Association into the Techa River in 1949-1956. Chelyabinsk and Salt Lake City: Urals Research Center for Radiation Medicine and University of Utah; Unscheduled report; August 2005 (in Russian and English).

\section{Milestone 17}

Degteva MO, Golikov VYu, Vorobiova MI, Barkovsky AN, Zubkova TI, Kozyreva OV, Anspaugh LR, Napier BA. Development of a protocol for the reconstruction of individual medical doses for members of the Extended Techa River Cohort. Chelyabinsk and Salt Lake City: Urals Research Center for Radiation Medicine and University of Utah; Final report for Milestone 17; September 2005 (in Russian and English).

\section{Unscheduled Report}

Shagina NB, Degteva MO, Tolstykh EI, Anspaugh LR. Napier BA. Dosimetric models for strontium in the human bone: A review of available data and researches needed. Chelyabinsk and Salt Lake City: Urals Research Center for Radiation Medicine and University of Utah; Unscheduled report; September 2005 (in Russian and English).

\section{Combined Milestones 11 and 12 Report}

Tolstykh EI, Shagina NB, Peremyslova LM, Degteva MO, Anspaugh LR, Napier BA. Methodological approaches to the reconstruction of radionuclide intake for residents of the East Urals Radioactive Trace and Karachay Trace. Chelyabinsk and Salt Lake City: Urals Research Center for Radiation Medicine and University of Utah; Final report for Milestones 11 and 12; April 2006 (in Russian and English).

\section{Milestone 13}

Vorobiova MI, Degteva MO, Peremyslova LM, Safronova NG, Shagina NB, Anspaugh LR, Napier BA. Methodological approaches to external dose reconstruction and validation for the EURT and 'Karachay trace' areas. Chelyabinsk and Salt Lake City: Urals Research Center for Radiation Medicine and University of Utah; Final report for Milestone 13; September 2006 (in Russian and English).

\section{Milestone 14}

Degteva MO, Tolstykh EI, Vorobiova MI, Shagina NB, Anspaugh LR, Napier BA. Comparative analysis of the possible impact of different sources of environmental and medical exposure 
for members of the Techa River cohorts. Chelyabinsk and Salt Lake City: Urals Research Center for Radiation Medicine and University of Utah; Final report for Milestone 14; April 2007 (in Russian and English).

\section{Milestone 18}

Shagina NB, Degteva MO, Tolstykh EI, Zalyapin VI, Krivoschapov VA, Tokareva EE, Anspaugh LR, Napier BA. Algorithm for selection of the best individual estimate of internal dose on the basis of the results of calculations performed using three different protocols. Chelyabinsk and Salt Lake City: Urals Research Center for Radiation Medicine and University of Utah; Final report for Milestone 18; April 2007 (in Russian and English).

\section{Milestone 19}

Degteva MO, Shagina NB, Vorobiova MI, Golikov VYu, Barkovsky AN, Kozyrev AV, Anspaugh LR, Napier BA. Reconstruction of individual medical doses for members of the Extended Techa River Cohort. Chelyabinsk and Salt Lake City: Urals Research Center for Radiation Medicine and University of Utah; Final report for Milestone 19; October 2007 (in Russian and English).

\section{Unscheduled Report}

Napier BA, Anspaugh LR, Degteva MO. Assessment of various types of uncertainty in the Techa River Dosimetry System. Chelyabinsk and Salt Lake City: Urals Research Center for Radiation Medicine and University of Utah; Unscheduled report; April 2008.

\section{Combined Milestones 20 and 21 Report, Part 1}

Degteva MO, Tolstykh EI, Vorobiova MI, Shagina NB, Anspaugh LR, Napier BA. Structure of the revised Techa River Dosimetry System: General approach and evaluation of sourceterm parameters. Chelyabinsk and Salt Lake City: Urals Research Center for Radiation Medicine and University of Utah; Combined report for Milestones 20 and 21, Part 1. October 2008.

\section{Unscheduled Report}

Tolstykh EI, Shagina NB, Krivoshchapov VA, Degteva MO, Shishkina EA, Anspaugh LR, Napier BA. Improvement in Strontium-90 reference intake function for residents of the Techa Riverside settlements. Chelyabinsk and Salt Lake City: Urals Research Center for Radiation Medicine and University of Utah; Unscheduled report; October 2008.

\section{Unscheduled Report}

Tolstykh EI, Shagina NB, Peremyslova LM, Safronova NG, Degteva MO, Anspaugh LR, Napier BA. Improvement in cesium-137 intake with milk contaminated as a result of soil $\rightarrow$ 
grass $\rightarrow$ milk transfer. Chelyabinsk and Salt Lake City: Urals Research Center for Radiation Medicine and University of Utah; Unscheduled report; October 2008.

\section{Unscheduled Report}

Vorobiova MI, Degteva MO, Safronova NG, Akhramenko BN, Anspaugh LR, Napier BA. Methodological approaches to evaluation of parameters for external exposure of the Techa River residents. Chelyabinsk and Salt Lake City: Urals Research Center for Radiation Medicine and University of Utah; Unscheduled report ; October 2008.

\section{Combined Milestones 20 and 21 Report, Part 2}

Degteva MO, Tolstykh EI, Vorobiova MI, Shagina NB, Kozyrev AV, Anspaugh LR, Napier BA. Structure of the revised Techa River Dosimetry System: Exposure pathways and system databases. Chelyabinsk and Salt Lake City: Urals Research Center for Radiation Medicine and University of Utah; Combined report for Milestones 20 and 21, Part 2; April 2009.

\section{Milestone 22}

Degteva MO, Shagina NB Tolstykh EI, Vorobiova MI, Anspaugh LR, Napier BA. Individual dose calculations with use of the Revised Techa River Dosimetry System TRDS-2009D. Chelyabinsk and Salt Lake City: Urals Research Center for Radiation Medicine and University of Utah; Final Report for Milestone 22; October 2009.

\section{Milestone 23 Status Report}

Napier BA, Degteva MO, Anspaugh LR, Shagina NB. Assessment of uncertainty in the radiation doses for the Techa River Dosimetry System. Chelyabinsk and Salt Lake City: Urals Research Center for Radiation Medicine and University of Utah; Status report for Milestone 23; October 2009.

\section{PROGRESS REPORTS}

\section{December 1996 - Original Proposal}

Degteva MO, Drozhko E, Anspaugh L, Napier B, Bouville A, Miller C. Development of an improved dose reconstruction system for the general population affected by the operation of the Mayak Production Association. Proposal (protocol) for continuation of Joint Coordinating Committee on Radiation Effects Research Project 1.1. Livermore and Chelyabinsk: Lawrence Livermore National Laboratory and Urals Research Center for Radiation Medicine; UCRL-PROP-126084; December 1996. 


\section{June 1997—Revised List of Tasks and Milestones}

Degteva MO, Anspaugh L, Napier B, Bouville A, Miller C. Development of an improved dose reconstruction system for the general population affected by the operation of the Mayak Production Association. Update on Project 1.1 tasks and milestones. Chelyabinsk and Livermore: Urals Research Center for Radiation Medicine and Lawrence Livermore National Laboratory; June 1997.

\section{March 1998 Progress Report}

Degteva MO, Anspaugh L, Napier B, Bouville A, Miller C. Development of an improved dose reconstruction system for the general population affected by the operation of the Mayak Production Association. Progress report on Project 1.1. Chelyabinsk and Salt Lake City: Urals Research Center for Radiation Medicine and University of Utah; March 1998.

\section{October 1998 Progress Report}

Degteva MO, Anspaugh L, Napier B, Bouville A, Miller C. Development of an improved dose reconstruction system for the general population affected by the operation of the Mayak Production Association. Progress report on Project 1.1. Chelyabinsk and Salt Lake City: Urals Research Center for Radiation Medicine and University of Utah; October 1998.

\section{March 1999 Progress Report}

Degteva MO, Anspaugh L, Napier B, Bouville A, Miller C. Development of an improved dose reconstruction system for the general population affected by the operation of the Mayak Production Association. Progress report on Project 1.1. Chelyabinsk and Salt Lake City: Urals Research Center for Radiation Medicine and University of Utah; March 1999.

\section{July 1999 Unscheduled Progress Report}

Degteva MO, Anspaugh L, Napier B, Bouville A, Miller C. Development of an improved dose reconstruction system for the general population affected by the operation of the Mayak Production Association. Unscheduled progress report on Project 1.1. Chelyabinsk and Salt Lake City: Urals Research Center for Radiation Medicine and University of Utah; July 1999.

\section{September 1999 Progress Report}

Degteva MO, Anspaugh L, Napier B, Bouville A, Miller C. Development of an improved dose reconstruction system for the general population affected by the operation of the Mayak Production Association. Progress report on Project 1.1. Chelyabinsk and Salt Lake City: Urals Research Center for Radiation Medicine and University of Utah; September 1999. 
June 2000 - Continuation Proposal for the Second Phase of Project 1.1

Degteva MO, Anspaugh L, Napier B. Further studies on uncertainty, confounding, and validation of the doses in the Techa River Dosimetry System. Proposal for the continuation of Project 1.1. Chelyabinsk and Salt Lake City: Urals Research Center for Radiation Medicine and University of Utah; June 2000.

\section{October 2000 Progress Report}

Degteva MO, Anspaugh L, Napier B. Further studies on uncertainty and validation of the doses in the Techa River Dosimetry System. Progress report on Project 1.1. Chelyabinsk and Salt Lake City: Urals Research Center for Radiation Medicine and University of Utah; October 2000.

\section{April 2001 Progress Report}

Degteva MO, Anspaugh L, Napier B. Further studies on uncertainty and validation of the doses in the Techa River Dosimetry System. Progress report on Project 1.1. Chelyabinsk and Salt Lake City: Urals Research Center for Radiation Medicine and University of Utah; April 2001.

\section{October 2001 Progress Report}

Degteva MO, Anspaugh L Napier B. Further studies on uncertainty and validation of the doses in the Techa River Dosimetry System. Progress report on Project 1.1. Chelyabinsk and Salt Lake City: Urals Research Center for Radiation Medicine and University of Utah; October 2001.

\section{April 2002 Progress Report}

Degteva MO, Anspaugh L, Napier B. Further studies on uncertainty and validation of the doses in the Techa River Dosimetry System. Progress report on Project 1.1. Chelyabinsk and Salt Lake City: Urals Research Center for Radiation Medicine and University of Utah; April 2002.

\section{July 2002—Proposed Addendum to Study Protocol}

Degteva MO, Anspaugh L, Napier B. Further studies on uncertainty and validation of the doses in the Techa River Dosimetry System. Project 1.1. Addendum to study protocol: Feasibility study for the reconstruction of individual dose due to medical exposure for members of the Extended Techa River Cohort. Chelyabinsk and Salt Lake City: Urals Research Center for Radiation Medicine and University of Utah; July 2002. 


\section{October 2002 Progress Report}

Degteva MO, Anspaugh L, Napier B. Further studies on uncertainty and validation of the doses in the Techa River Dosimetry System. Progress report on Project 1.1. Chelyabinsk and Salt Lake City: Urals Research Center for Radiation Medicine and University of Utah; October 2002.

\section{April 2003 Progress Report}

Degteva MO, Anspaugh L, Napier B. Further studies on uncertainty and validation of the doses in the Techa River Dosimetry System. Progress report on Project 1.1. Chelyabinsk and Salt Lake City: Urals Research Center for Radiation Medicine and University of Utah; April 2003.

\section{April 2003-Proposed Extension to Study Protocol}

Degteva MO, Anspaugh L, Napier B. Further studies on uncertainty and validation of the doses in the Techa River Dosimetry System. Project 1.1. Proposal (protocol) for extension of Project 1.1. Chelyabinsk and Salt Lake City: Urals Research Center for Radiation Medicine and University of Utah; April 2003.

\section{October 2003 Progress Report}

Degteva MO, Anspaugh L, Napier B. Further studies on uncertainty and validation of the doses in the Techa River Dosimetry System. Progress report on Project 1.1. Chelyabinsk and Salt Lake City: Urals Research Center for Radiation Medicine and University of Utah; October 2003.

\section{April 2004 Progress Report}

Degteva MO, Anspaugh L, Napier B. Further studies on uncertainty and validation of the doses in the Techa River Dosimetry System. Progress report on Project 1.1. Chelyabinsk and Salt Lake City: Urals Research Center for Radiation Medicine and University of Utah; April 2004.

\section{October 2004 Progress Report}

Degteva MO, Anspaugh L, Napier B. Further studies on uncertainty and validation of the doses in the Techa River Dosimetry System. Progress report on Project 1.1. Chelyabinsk and Salt Lake City: Urals Research Center for Radiation Medicine and University of Utah; October 2004. 


\section{April 2005 Progress Report}

Degteva MO, Anspaugh L, Napier B. Further studies on uncertainty and validation of the doses in the Techa River Dosimetry System. Progress report on Project 1.1. Chelyabinsk and Salt Lake City: Urals Research Center for Radiation Medicine and University of Utah; April 2005.

\section{October 2005 Progress Report}

Degteva MO, Anspaugh L, Napier B. Further studies on uncertainty and validation of the doses in the Techa River Dosimetry System. Progress report on Project 1.1. Chelyabinsk and Salt Lake City: Urals Research Center for Radiation Medicine and University of Utah; October 2005.

\section{April 2006 Progress Report}

Degteva MO, Anspaugh L, Napier B. Further studies on uncertainty and validation of the doses in the Techa River Dosimetry System. Progress report on Project 1.1. Chelyabinsk and Salt Lake City: Urals Research Center for Radiation Medicine and University of Utah; April 2006.

\section{April 2006_-Proposed Extension to Study Protocol}

Degteva MO, Anspaugh L, Napier B. Further studies on uncertainty, confounding and validation of the doses in the Techa River Dosimetry System. Project 1.1. Proposal (protocol) for extension of Project 1.1. Chelyabinsk and Salt Lake City: Urals Research Center for Radiation Medicine and University of Utah; April 2006.

\section{October 2006 Progress Report}

Degteva MO, Anspaugh L, Napier B. Further studies on uncertainty, confounding and validation of the doses in the Techa River Dosimetry System. Progress report on Project 1.1. Chelyabinsk and Salt Lake City: Urals Research Center for Radiation Medicine and University of Utah; October 2006.

\section{April 2007 Progress Report}

Degteva MO, Anspaugh L, Napier B. Further studies on uncertainty, confounding and validation of the doses in the Techa River Dosimetry System. Progress report on Project 1.1. Chelyabinsk and Salt Lake City: Urals Research Center for Radiation Medicine and University of Utah; April 2007. 


\section{October 2007 Progress Report}

Degteva MO, Anspaugh L, Napier B. Further studies on uncertainty, confounding and validation of the doses in the Techa River Dosimetry System. Progress report on Project 1.1. Chelyabinsk and Salt Lake City: Urals Research Center for Radiation Medicine and University of Utah; October 2007.

\section{April 2008 Progress Report}

Degteva MO, Anspaugh L, Napier B. Further studies on uncertainty, confounding and validation of the doses in the Techa River Dosimetry System. Progress report on Project 1.1. Chelyabinsk and Salt Lake City: Urals Research Center for Radiation Medicine and University of Utah; April 2008.

\section{October 2008 Progress Report}

Degteva MO, Anspaugh L, Napier B. Further studies on uncertainty, confounding and validation of the doses in the Techa River Dosimetry System. Progress report on Project 1.1. Chelyabinsk and Salt Lake City: Urals Research Center for Radiation Medicine and University of Utah; October 2008.

\section{April 2009 Progress Report}

Degteva MO, Anspaugh L, Napier B. Further studies on uncertainty, confounding and validation of the doses in the Techa River Dosimetry System. Progress report on Project 1.1. Chelyabinsk and Salt Lake City: Urals Research Center for Radiation Medicine and University of Utah; April 2009.

\section{April 2009—Proposal for the Third Phase of Project 1.1}

Degteva MO, Anspaugh L, Napier B. Enhancements in the Techa River Dosimetry System. Proposal for the continuation of Project 1.1. Chelyabinsk and Salt Lake City: Urals Research Center for Radiation Medicine and University of Utah; April 2009.

\section{October 2009 Concluding Progress Report on the Second Phase of Project 1.1}

Degteva MO, Anspaugh L, Napier B. Further studies on uncertainty, confounding and validation of the doses in the Techa River Dosimetry System. Concluding progress report on the second phase of Project 1.1. Chelyabinsk and Salt Lake City: Urals Research Center for Radiation Medicine and University of Utah; October 2009. 